\title{
NATURAL GLASS ANALOGUES TO ALTERATION OF NUCLEAR WASTE GLASS: A REVIEW AND RECOMMENDATIONS FOR FURTHER STUDY
}
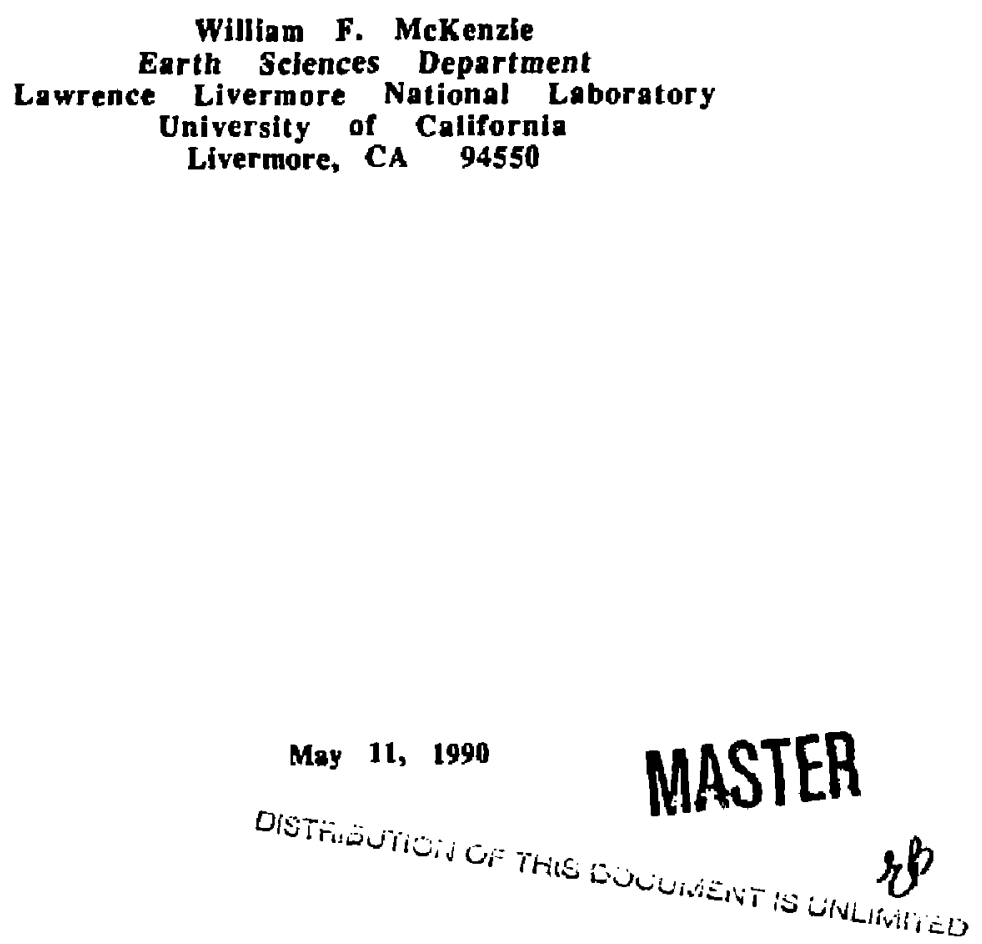


\section{TABLE OF CONTENTS}

$\begin{array}{lr} & \text { RAGE } \\ \text { JNTRODUCTION } & 1 \\ \text { NATURAL ANALOGUES } & 2 \\ \text { NATURAL GLASSES } & 3 \\ \text { PALAGONITIZATION } & 4 \\ \text { SECONDARY MINERALIZATION } & 6 \\ \text { JCC STUDY OF BASALTIC GLASSES } & 7 \\ \text { FROM ICELAND AND THE DEEP SEA } & 8 \\ \text { ARGONNE STUDY OF BASALTIC GLASSES } & 10 \\ \text { RECOMMENDATIONS FOR FURTHER STUDY } & 16 \\ \text { REFERENCES } & \end{array}$




\section{INTROEUCTION}

The purpose of this repon is to review previous work on the weathering of natural glasses; and, to make recommendations for further work with respect 10 studying the alteration of natural glasses as it relates to quantifying rates of dissolution. The first task was greatly simplified by the published papers of Jercinovic and Ewing (1987) and Byers, Jercinovic, and Ewing (1987). The second task is obvicusly the more difficult of the two and the author makes no claim of completeness in this regard. Glasses weather in the natural environment by reacting with aqueous solutions producing a rind of secondary solid phases. It has bect proposed by some workers that the thickness of this rind is a finction of the age of the glass and thus coufd be used to estimate glass dissolution rates. However, Jercinovic and Ewing (1987) point out that in general the rind thickness docs not corrclatc with the age of the glass owing to the differences in time of contact with the solution compared to the actual age of the sample. It should be noted that the the rate of glass dissolution is also a function of the composition of both the glass and the solution, and the temperature. Quantification of the effects of these parameters (as well as time of contact with the aqueous phase and flow rates) would thus permit a prediction of the consequences of glass-fluid interactions under varying environmental conditions.

Defense high-level nuelcar waste (DHLW), consisting primarily of liquid and sludge. will be encapsulated by and dispersed in a borosilicate glass before permanent storage in a HLW repository. This glass containing the DHLW scrves to dilute the radionuclides and 10 retard their dispersion into the environment. DHLW is temporarily being stored at the Savannah River Plant in South Carolina, the Hanford Rescrvation in Washington, and the Idaho National Engineering Laboratory in: Idaho. This HLW is primarily from the production of nuclear materials. In addition to the defense waste, there is a small amount of civilian liquid HLW at West Valicy, New York that will also be converted to glass before permanent storage. This civilian waste was crsaled by some limited reprocessing of spent fucl rods.

The Nuclear Regulatory Cammission regulations (10 CFR 60) statc that the containment of HLW within the waste packages must be substantially complete for a period of 300 to 1,000 years after permanent closure of the geologic repository: and that the release rate of any radionuclide from the enginecred barrier system following the containment period shall not exceed one part in 100,000 per year of the inventory of that radionuclide calculated to be present at 1,000 ycars following permanent closurc. or as otherwise approved by the Commission.

The requirement to predict materials performance and the geological environment over long periods of lime is unprecedented. Field and laboratory experiments are carricd out for only short periods of time relative to the period over which a repository must maintain integrity. Consequently the prediction of radionuclide relcase rates from the waste form ("source tems") must be madc by models that extrapolate data obtained in short-term experiments, such as glass leaching ralcs, to longer times. Such an extrapolation from tests lasting from months to years to predicting the consequences over 10,000 years must be demonstrated to be valid. 


\section{NATURAL ANALOGUES}

Natural analogs in general can be useful in extrapolating short-term experiments to longer time frames. However it is doubtful that natural analogs can provide all the necded quantitative data to reasonably assure that a HLW repository will maintain its integrity over long periods of time. Nevertheless, studics of natural analogs should provide information rcgarding the reasonableness of projections about repository integrity. Natural analogs have been proposed for the glass waste form, metal containers, and for radionuclide movement. The latte: natural analogs will only be briefly mentioned herc as the focus of this report is on natural glass analogues to alteration of nuclear waste glass.

Metal objects such as naturally occurring pure copper, pure iron, and iron meteorites have been preserved in the geologic record for millions of ycars. Some iron meteoritic material has been extant since the time of the Egyptian Pharaohs in the form of a dagger with a blade resembling stainless steel. The blade is quite high in nickel and cobalt content and upon etching or corrosion reveals a Widmanslatten pattern that is unique to iron meteorites. This material is of particuiar interest owing to the present plans to store nuclear waste in stainless stecl, also an iron alloy containing nickel.

The natural analog of radionuclide movement in the earth's crust that probably is the most similar 10 an actual nuclear waste repository is the uranium deposit at Oklo in Gabon (revicwed by Brookins, 1987). Other than at Oklo, natural uranium ores throughout the world yield values of near $0.71 \% 235 \mathrm{U}$. Oklo ores range as low as $0.3 \%$ $235 U$. Evidence points to the $235 \mathrm{U}$ at Oklo being consumed by neutron-induced fission when the deposit became a natural reactor about $\vec{z}$ billion years ago since therc arc also present fission products found associated with the depleted ore. Detuils remain unclear on how the ore at Oklo became high grade, enriched in $235 \mathrm{U}$ in greater than 2-3\%, and with a water content at between $12-16 \%$ - all necessary to achieve criticality. Water at much less than $12 \%$ would be ion little to scrve as an efficient moderalor and water much greater than $16 \%$ would allow the neutron flux to become too diffuse. Natural fission reactors are therefore expected 10 be excecdingly rare and indecd only Oklo has thus far been found in the geologic record. Oklo is an uniquely important natural analog owing to the fact that actinides are produced during fissioning whercas most actinides (exceptions being thorium and uranium) are generally present only in trace amounts in nature. Furthermore the actinide elements have no non-radioactive elements that can serve as proxies as is the case for other clements such as strontium, where both radioactive and non-radioaclive isotopes behave chemically similar. Thus other than introducing actinides into a repository, one of the few places to obtain actinide migration rates in a natural setting $_{0}$ is at Oklo.

Natural glasses similar in bulk composition to that of the HLW glas: are found in nature and have been subjected to conditions similar to that expected if the repository is flooded with water and the canisters are breached allowing groundwater to reacl with the glass waste form. Careful study of these natural analogues could provide the necessary link between theoretical models and short-term laboratory tests 10 provide information regarding the long-term integrity of the glass-waste form. In olher words models developed to extrapolate data obtained in short-tcrm experiments could be validated by catefil observation of the geologic record which has preserved information for time frames from hundreds to millions of years. This long-term information is not obiainable from laboratory experiments, in situ tests, or, 
presently, $a b$ initio calculations. Geochemical modeling codes such as Path (R. G. Berman and T. H. Brown, pers, comin., 1988), Gt (C. Bethke, pers. comm., 1988), and EQ3/6 (Wolery, 1979) are not presently capable of predicting the changes resulting from rock-water-glass inicractions owing to the restrictions imposed by an inadequate data base, particularly in regards to the thermodynamic properties of relevant mincral phases and rate constants for reactions, and an inadequate conceptual model to account for components in the glass. In addition the coupling of hydrologic flow with chemical reactions (reactive transport) has not becn successfully achicved.

\section{NATURAL GLASSES}

A varicty of glasses are not man-made but have formed naturally: basaltic glasses, rhyolitic glasses, lunar glasses, meleoritic glasses, and tektites (Ewing, 1978; Ewing and Haaker. 1979) and these glasses have ages from months to millions of years. Samples of meteoritic glasses are relalively tare and albeit interesting will not be discussed further in this report.

Tckities occur as glassy bodies, botlle-green to blackish, and range in size from fractions of a millimeter 10 tens of centimeters in diameler. They generally are found strewn across wide areas ${ }_{2}$, to $10,000 \mathrm{~km}$ wide and range in age from a few hundreds of thousands of years to more than 35 million years. Their origin is thought to be associated with the impacts of giant meteorites. It is rare that any alteration. hydration, or devitrification of tektites is noted. This is the case even for tektites observed in clder sediments recovered from decp-sea cores and which were subjected to scawater for periods up to millions of years. This durability is gencrally attributed to the high silica content ( $>65 \mathrm{wt} \%$ ), high silica + alumina (usually $>80 \%$ ). lcw alkali and alkailine carth oxide content, and low water content $(<0.01$ wt \%) (Ewing and Jercinovic, 1987). However, there is a class of tektites that are much lower in silica content. Bottle-green téktites have compositions that exiend to $50 \%$ silica and lower (Glass, 1972) which is in the range of silica composition proposed for high-level nuclear wastc glass. The average depth of corrosion of tektites from the deep oceans was found by Glass to be about $2 \pm 2$ micrometers for tectites of $72 \%$ silica to about $14 \pm$ 5 micrometers for tectites of $54 \%$ silica. The tectites with low silica values were found only in arcas with ages of less than one million years. Barkatt cl al. (1984; 1986) conducted leaching experiments on these glasses and found that the rates were 30 times greater in deionized wates compared to that in seawater and that extrapolated laboratory tests are in approximate agreement with ficld abscrvations of tekite corrosion. Barkalt's group (sec Maggs, 1988) have proposed that magnesium serves 10 prolecl the glasses from rapid corrosion. Crovisier and Honnorez (1988) have guestioned the role of magnesium in reducing corrosion rates and have stated that it is not prescntly possible to conclude that any one factor will lead to a decrease in glass corrosion.

Lunar glasses are of interest as they have remained stable for up to 4 billion years and show no traces of alteration or crystallization (Roedder and Wieblen. 1971). The utilization of lunar glasses for natural analogue studies is precluded owing to the high eost of ficld colleclions. Nevertheless, the observed stability of lunar glasses substantiates the notions that glasses can disappear in the natural cnvironment by Iwo mechanisms:

- Glasses can react with water which in tum increases the conceatration of glass components in solution and also p.:-Juces secondary non-glassy mineral phases 
such as clays and zeolitcs - a precess that some workers term glass dissolution or corrosion.

- Glasses can convert to a more stable crystalline state - a process known as devitrification.

In the case of an anhydrous environment, it is expected that glasses would be subject only to devitrificatior over time. Under anhydrous conditions and at low temperatures $\left(<25^{\circ} \mathrm{C}\right)$, the ume required for devitrification exceeds the age of lunar glasses by many orders of magnitude (Marshall, 1961). At high iemperatures Rutley (1886) demonstrated that natural glasses could be rcadily devitrified by heating a sample of obsidian from Ascension Island. Crystals up 1030 microns grew in less than a month when the obsidian was heated to between $850^{\circ} \mathrm{C}$ and $1100^{\circ} \mathrm{C}$.

Rhyolitic glasses typically contain approximately 70 wl\% silica. Although these glasses have been studied relatively intensely (e.g., Marshall, 1961; Friedman and Trembour, 1978; Dickin, 1981; Zielinskj, 1979; and White. 1983), they are of presenty less concern with respect to the focus of this report owing to their high silica composition. We could however learn more regarding the overall compositional dependency of the glass on corrosion rates by further study of these siliceous glasses.

It has been suggested that basaltic glasses could serve as natural analogues for nuclear waste glasses (c.g., Ewing, 1978; Ewing and Haaker, 1979; Adams, 1979; Ziclinski, 1980; Dickin, 1981; Bales el al., 1982; Allen, 1982; Plodinec, 1984; and Malow, et a], 1984) owing to similar compositions between the glasses and the obscrved increasing altcration of the nalural glasses with time. Two recent studics on basaltic glasses stand out: the JCC study of basaltic glasses from Iceland and the deep sea (Jercinovic and Ewing, 1987) and the Argonne study of basaltic glasses (Bycrs. Jercinovic, and Ewing, 1987). Following a discussion of palagonitization and secondary mineralization, these two studies will be reviewed in some detail as they represent the most thorough work pubrished to date regarding the dissolution rates of basaltic glass and how this relates to the glass waste form for high-level nuclear waste.

\section{PALAGONITIZATION}

W. Sarlorius von Waltersiuausen (1845) coined the term palagonite when he described a brewn material in the groundmass of a tuff from Palagonia in Sicily. Initially it was used to describe a wide range of scales of maicrial from deposits (Pjctursson, 1900) to that on a microscopic scale such as sideromclane (basaltic) glass (Peacock, 1926; Peacock and Fuller. 1928). Palagonite is now used to describe the reddish to yellow-brown, gel-like material that is the altcration producl of sideromelane glass (Nayudu, 1964; Hay and lijima 1968a, 1968b; Allen el al., 1981).

As reviewed by Jercinovic and Ewing (1987), the physical and chemical preperties of palagonite have been studied by numerous rescarchers (c.g., Hay and Iijima 1968a, 1968b; Honnores, 1972; Jakobsson, 1972; Singer, 1974; Furnes 1978, 1980. 1984; Fumes and El-Anbaawy. 1980; Allen et al., 1981; Staudigel and Hart. 1983). The glass-palagonite contact is generally sharp (Hay and lijima, 1968b; Geptncr. 1978), characterized by pitted or etched glass surface (Hay and Jones, 1972; Allen ct al., 1981), and sometines exhibits penetration by microchannels (Staudigel and Hart, 1983) which may be the same as the "rootlet intergrowth" observed by Geptner (1978). The refractive index of palagonite ranges in values from 1.46 to 1.70 (Hay and Iijima 
1968a, 1968b; Stokes, 1971) and the specific gravity of palagonite ranges in values from 1.93 to 2.42 (Hay and lijima 1968a, 1968b; Fumes, 1978).

Mechanisms proposed for palagonitization include: solution precipitation, or hydrogen-ion metasomatism, (Hay and Sjima 1968b; Hay and Jones, 1972), hydration (Peacock, 1926; Morgenstein and Riley, 1974), and solid-state diffusion accompanied by hydration (Moore, 1966). Palagonitization has been observed over a wide tcmpcrature range and lime scales from almost instantaneous to thousands of years. For example. Bonatti (1965) observed immediate palagonitization associated with magma cruption at high temperatures, Hay and lijima (1968a, 1968b) observed palagonitization at low temperatures assocjated with sediments and that the palagonitization took place over thousands of years, and Jokobsson (1978) and Jakobsson and Moore (1986) observed palagonitization on Surtsey volcano at temperatures from $40^{\circ} \mathrm{C}$ to $150^{\circ} \mathrm{C}$ a few years after eruption. Thus as expected the rate of palagonitizalion increases with temperature which is in agrecment with cxperimental studies (Moore, 1966; Moore, et al. 1995). Jercinovic and Ewing (1987) reached the following conclusions from reviewing the general characteristics of palagonitc that are evident from published data (c.g.. Bonatti, 1965; Hay and lijima 1968a, 1S68b; Hay and Jones, 1972; Muffler el al., 1969; Honnorex, 1972; Jakobsson, 1972; Melson, 1973; Singer, 1974; Fumes, 1978, 1980, 1984; Juteau et al., 1979; Fumes and ElAnbaawy, 1980; Ailin-Pyzik and Sommer, 1981; Allen et al., 1981; Staudigel and Hart, 1983; and Jakobsson and Moore, 1986):

- palagonitization is not a simpie hydration process and is a nonisochemical (metasomatic) process;

- palagonite composition varies from one occurrence 10 another: and,

- palagonites of chemically different composition can be derived from chemically and physically similar glasses, indicating the importance of solution composition, temperature, flow rate, etc.

In general most elements are depleted during palagonitization with only minor losses obscrved in most cases for aluminum, iron, and titanium. Concentrations of elements that form relatively insoluble substances and are enriched in the glass phase are found in greater abundance in the palagonile formed from such a glass. For cxample, glasses that are rich in iron and titanium form palagonitcs that are more concentrated in these elemenls than are palagonites formed from glasses relatively depleted in iron and titanium (Fumes and El-Anbaaey, 1980). Palagonites produced in a marine cnvironment can be enriched in more mobile elements such as potassium and sodjum (Andrews, 1977; Baragar et al. 1977; Bonatti, 1965: Melson, 1973: Pritchard et al., 1978; Jutcau et al., 1979; Staudigel and Hart, 1983; and Szarfe and Smith, 1977). Jercinovic and Ewing (1977) have summarized that the composition of palagonitc results from threc factors:

- the chemical composition of the glass and its physical propertics;

- the chemical composition of the aqueous solution land the attendant temperalure and pressure under which the palagonitization oceurs]: and,

- the duration during which alteration of the glass takes place - this is particularly important in systems where the water-rock ratio is extremely small which in Iurn will greally effect the composition of the liquid phasc. 
Rates of palagonitization have been estimated in "fresh" water and scawater at temperatures from 5 to $50^{\circ} \mathrm{C}$ in the natural environmenl and range in value from 3 to 30 microns/1000 years (Moore, 1966; Morgenstein and Riley, 1974; Hekinian and Hoffert, 1975: Moore, et al. 1985: Grambow et al. 1985; and, Jakobsson and Moorc, 1986). Experimental palagonitization studies have also resulted in estimatcs for rates of palagonitzation (Fumes, 1975; Malow et al., 1984; Crovisier, 1985; and Crovisier et al. 1986) which are sorewhat higher than estimates from the natural cuvironment - up to 180 microns $/ 1000$ years

Fumes (1975) observed in his experimental work over 14 months that the rate of palagonitization increases dramatically with temperature and was not lincar with time. For alkali basalt glass the rate was about 0.3 micsons/mnnth for the first I0 months at temperatures from 20 to $70^{\circ} \mathrm{C}$, and increased to $3.3 \mathrm{microns} / \mathrm{month}$ after 10 months for temperatures greater than $70^{\circ} \mathrm{C}$. Siudies of the Surtscy corcs (Jikobsson and Moore, 1982, 1986) have also indicated the rapid increase in palagonitization wilh an increase in temperature. Al $4^{\circ} \mathrm{C}$ the rate at Surlsey was 15 microns $/ 1000$ years whereas at $12^{\circ} \mathrm{C}$ the rate doubled. Moore et al. (1985) made similar obscrvations at Hawaii where they found that the rate increased 1.8 times for a temperature increase of $10^{\circ} \mathrm{C}$.

As noted by Jercinovic and Ewing (1987), if one assumes a rale of 2 microns 1000 year as being a good estimatc for palagonitization, centimcter-thick glassy rims on a piliow basalt would be completely palagonitized in less than five million years; and hyaloclastites with an average grain size less than $2 \mathrm{~mm}$ would be completely palagonitized in less than one million years. There are, however, abundant observations that fail to corroborate thesc estimatus. For cxample fresh glass is found in drill core samples of much grealer age: in Deep Sca Drilling Program (DSDP) Hole 408 glass was found that was $20 \mathrm{~m} . y$. (Luyendyk el al. 1978); DSDP 407. 35 m.y.. (Luyendyk et al., 1978); LSDP 382, 70 to 80 m.y. (Tucholke et al., 1979), and DSDP 417 and 418, 105 to 110 m.y. (Donnelly et al., 1979). In addition there is unaltered glass found in the Miocene Frenchman Springs Flow of the Wanapum Basilts, 12 to 14 m.y., in the Columbia River Basalt Group (Jercinovic. Ewing, and Byers, 1986), in submarine-produced hyaloclastics, now subacrialty cxposed, in the Hound Island Volcanics that are about 200 m.y. (Mufler, et al., 1969), and in the 340 m.y. Lahn Dill deposits (Schmincke and Pritchard. 1981). Thereforc one cannot assume a singular, linear alteration rate 10 explain the persistence of glass through geologic time for all glasses. Schminke ti al. (1978) postulate that a scaling process has prescrved glasses in the deep ocean sediments. Muffler e! al. (1969) suggested that calcitc precipitation has protected the glasses found at the Hound Island volcanics from alteration. Keith and Staples (1985) observed that sealing could also account for the preservation of glasses that are 35 to 55 million years old found in the Siletz River volcanics or western Oregon.

\section{SECONDARY MINERALIZATION}

Zeolites, smectites, and calcite are the most common mincrals associated with palagonitization. Analcime, phillipsite, and chabazite are the most commonly observed zeolites (Jercinovic and Ewing. 1987) and it is likely that the particular zcolite formed is a function of glass composition. fluid composition, and temperature. Mordenitc, heulandite, stilbitc, and cpistilbitc arc found in tholciitc basalts (Kristmannsdoltir, 1978) whereas chabazite, thomsonite, and mesolite-scolecitc arc 
found in the less siliceous olivine-tholeitc basalts. Mordenite, heulandite, stilbite, cpistilbitc. chabazite, thomsonite, and mesolite-scapolite are found where temperatures were less than $100^{\circ} \mathrm{C}$ whereas they are replaced by laumontite in the temperature interval of 100 to $120^{\circ} \mathrm{C}$ (Kristmannsdottir, 1978) and all zeolites disappear above $230^{\circ} \mathrm{C}$ (Tomasson and Krisımannsdottir, 1972).

Chlorite, montmorillonitc, Fe-saponite, and nontronite are the most commonly obscrved elays associated with palagonitization. Nontronite, as well as celadonite, appear to form at low temperature in the deep oceans and under oxidizing conditions (Kurnusov et al, 1982) whereas saponite forms at higher temperatures under nonoxidative conditions (Stakes and O'Neil, 1982). Chlorite is found in only those glasses that have been hydrothermally altered (Tomasson and Kristmannsdoltir, 1972).

\section{JCC STUDY OF BASALTIC GLASSES FROM ICELAND AND THE DEEP SEA}

This study (Jercinovic and Ewing, 1987) focused on the alteration process and products from nalural basaltic glasses. Amorphous leached laycjs were examined using analytical cleciron microscopy (AEM) which revealed that the leached layers arc not completely amorphous, but contain a relatively high proportion of crystalline phases, primarily as smectite-type clays. In addition there wcre found channels through the layers which provide access for solutions 10 react with the fresh glassfalteration layer interfacc. Jercinovic and Ewing conclude that glasses are not "protected" from further reaction by the formation of a surface layer.

Corrosion rates were not readily extracted from the examination of natural samples owing to the fact that the contact time of the solution with the glass was difficult to establish accuratcly. Nevertheless the authors concluded that there was evidence that corrosion procecds at two rates: (1) an initial rate, $k^{+}$, in silicaundersaturated environments and (2) a long-term rate, $k$, in silica-saturated environments. This evidenec is based on the long-term survival of glass once buried. Porc fluids in buried occanic sediments approach saturation with respect to silica. Jercinovic and Ewing felt that this was significant as it supported :he fundamental premises of the GLASSOL model (Grambow, 1987), but also supports the notion that there is no change in corrosion rates over long lime periods. The long-term corrosion rate estimated for natural basalt glasses exposed to sea water on the ocean foor was a minimum of 0.01 microns $/ 1000$ ycar.

Basaltic glasses from submarize deposits near the coast of Iccland and from subglacial-volcanic Irposits were analyzed for alteration. Palagonitc was the main alicration producl regardless of the cnvironment or age of the sample, and forms rinds on the glass surface as a reddish, vitreous product. It is suggested by petrographic examination that palagonitization is isvvolumetric. with the possible exception of some deep sea palagonites that are relatively concentrated in iron and depleted in silica. The subglacial-volcanic palagonites form a rind that is composed of colloidal material that could be natronite. Jercinovic and Ewing observed that palagonite appears to be amorphous by Scanning Electron Microscopy (SEM) and optical microscopy whereas Analytical Electron Microscopy (AEM) detecis crystallinity and microstructure and zoning of these features as well as zoning in chemical composition within the palagonitc rinds. 
Palagonite formed in scawater is enriched in alkalis and iron comparce to palagonite formed in fresh water. The potassium enrichment for seawater palagonites suggest that they may be more like an illite. There is sone titanium depletion, especially in deep sea samples, relative to the parent glass for which the cause is presently not known. No major compositionai difference was found between samples on the ocean floor collected by dredging or samples from occanic dritl cores suggesting that the drill core glasses may have undergone palagonitization in the open ocean before burial. Nevertheiess, there were found compositional gradients in the rinds which were more strongly developed in the palagonites that formed zeolites and were low in aluminum. The calcium and aluminum conecntiations increas toward the interior and later-formed parts of the rinds with iron and magnesium concentrations decreasing correspondingly. The gradients were thought to be due to the varying solution composition, such as $\mathrm{pH}$, as hydrolysis of the glass takes place in a closed systern. There was also found some zoning where zeolites werc nol associated with the rinds, but although similar in pattern the zoning was lower in cragnitude.

Jercinovic and Ewing observed that aluminum must be depleted in the rind relative to the parent glass in order for zeolites 10 form. Zeolites in generaj form in closed or nearly closed systems when flow rates are slow and following high reaction progress suggesting a high pH. It was obscrved that relatively thick rinds resu:: from high dissolution rates at correspondingly high $\mathrm{pH}$, or if the glass was subjected to very long exposuse to the solution. If significant alumisum is icached during palagonitization accompanied by a large water/glass ratio, zcolites nay not form. It was found that saponite will precipitate before zeolite if the relcase raic of magnesium + iron excesd that of calcilm during Icaching. Although phillipsite is not common in zeolitized Iceland samples, it is present in some ocicanic palagonilized glasses. The dominant zeolite in all the subglacial-volcanic glasses was chabazile, and. for all glasses, analcime was observed to be the last zeolite to form owing to the consumption of calcium and potassium by the earlicr-formed zeolites in a closed system. Little mass loss occurs when zeolites are formed based on mass balance calculations and elements required to form these authigeric phases probably come entircly from glass dissolution. There was obscrved a net mass loss of silicon, magnesium, calcium, sodium, and potassium if zeolites or clays do not form.

Jercinovic and Ewing concluded that the rind thickness of the palagonitc docs not correlate with age owing to the differences in time of contact with the solution compared to the actual age of the sample. As was pointed out above, the rates of palagonitization will also vary as a function of $\mathrm{pH}$ and silica concentration in the solution. Minimum palagonitization rates were estimated to be betwecn 0.01 to! microns/1000ycars and there were not any consistent differences in rind thickness between dredge and drill core samples despite the differences in silica concentrations in the interstitial waters compared to that in the sea water.

\section{ARGONNE STUDY OF BASALTIC GLASSES}

The alteration of natural basalt and nuclear waste glasses was studicd by the University of New Mexico and Argenne National Laboratory (Byers, el al., 1986). Workers at the University of New Mexico characterized the reaction products assuciated with a variely of natural basaltic glasses and described in delail the alteration process of fresh glasses to those coated with authigenic malterials. ANL. conducted cxperiments attempting to mimic the natural alteratioi. process using synthetic glasses of basaltic composition. Where the glasses were subjected to water yapor at temperatures above $90^{\circ} \mathrm{C}$ there was found a similarity in alicration to that of 
the natural glasses altered in the natural environment. In addition a similar alteration process was found when synthetic nuclear waste glass (SRL 165) was subjected to similar conditions. The conclusion vras that both the naturai alteratioi of basaltic glass and water-vispor experiments can be used as an analogue in assessing the durpbility of HLW glass under conditions as could be found in a repository.

Samples of basaltic glasses collected included those altered by seawater, and fresh water (lakes, streams, groundwater, and glacial melt). The glass occurred as rims on rillow basalts or as vitric tuff, agglomerate, breccia, or icphra deposits (hyaloclasite). Ages of the sampies ranged from recent to 350 million jears and glass compositions ranged in silica conteni from 45 to 55 wt $\%$ and alkali oxide content belween 2 and $5 \mathrm{wl} \%$. Both the glasses and the altersation products were analyzed with the aim of detcrmining the physical, mincralogical, and chemical results of palagonitization. The results of these siudies showed that the glass alters to first an amorphous reaclion layer (palagonite) followed by some degree of secondary mineral formation. It was difficult to correlate the amount and rate of palagonitization with specific geolugic conditions. but it was found that the rcaction progress is a function of both time and temperature. Gereral conclusions reached by Byers et al. include:

- All samples werc palagonitized to some degrce regardless of environment or age and palagonite was found to replace baraltic glass on exposed surfaces such as pillow sur'sces, grain adges aiong fraclures, and vesicles. In some cases the only sernrdary alteration product observed was palagonite, which compositionally resembles sicectite - Fe-saponite or nontronite.

- Si, $\mathrm{Mg}, \mathrm{Ca}, \mathrm{Na}, \mathrm{K}$, and $\mathrm{Mn}$ are depleted in the palagonitic rind relative to the glass in fresh water sctings whereas in seawater environments the rinds are cnricheo in $K$ and tolal alkalis. Generally, the titanium and iron are immobilized in the rinds as sparingly soluble oxides. Al can be depleted in some rinos and cnriched in others. but depleted Al rinds are often accompanied by silica enrichment relative to the glass composition.

The most-common alteration mincrals are clays which occur as a ecplacement of the palagonite and as ecment. The clays observed are smectilekaolinitc clays and Fe-rich smectities. Fe-saponitc is found in samples of all cnvironments and ages and is the most conmonly found clay. Although clays are found in samples that are relativcly little pa.agonitized, whese there clearly is a contribution of material from the solution or non-glass seurces. In general the composition of the clays represent the telative proportions of material lcached from the glass. The nexi most common authigenic minerals are zcolites and calcite. The compositions of the zcolites reflect the proporions of elements relcased during palagonitization or that remaining after the formation of claye. The formation of zeolites does not appear to be directly related to the amount of glass reacted owing to the fact that if $\mathrm{Ca}$ and $\mathrm{Al}$ are not dissolved during the palagonitizalion process ar when clay replaces palagonite, zeolites do not form.

The rates for low-temperature alteration of glass which were estimated from the correlation of thickness and age for rinds from samples collectcd in subglacial volcanocs in British Columbia and lecland arc 31010 micrometers/1000 years. These ralcs werc considered to be ninimum rales as the actual cxposure time axc not known. 
Basaltic glass that was reacted in watcr vapor al elevated temperatures ( $>90^{\circ} \mathrm{C}$ ) formed first an amorphous layer and then sceondary minerals formed which included a smectite-type clay, analcime, gyrolite. thomsonite, aragonitc, and reyerisc. These same secondary phases had been previously identified in natural samples. There was extensive depletion of alkalis: relatively high depletion of $\mathrm{Si}, \mathrm{Al}$, and $\mathrm{Ca}$; and, immobilization of $\mathrm{Ti}$ and $\mathrm{Fe}$ - all consistent with natural palagonitization.

When the SRL 165 glass was reacted with hol watcr vapor, the results were similar to that of the basaltic glass with the exception that the rale of scaction for the SRL 165 glass was greater than that for the basaltic glass. Despite the differences in rates, the ANL group concluded that the same processes that control the vapor-phase alteration of the SRL 165 glass are also the processes that control the vapor-phase alteration of the basaltic glass owing to the similarity in altcration products and their compositions.

Byers et al. concluded that natural glass alters first to palagonitc and then to a series of authigenic minerals. However the correlation of palagonitization and gcologic conditions was difficult to generalize because of the variability of the cnvironmental conditions with time. There was observed a similarily in the alteration of natural basaltic glass, synthctic basaltic glass, and nuclcar wastc glass (SRL 165) and therefore the natural alicration of basallic glass can be used as an analogue for assessing the performance of HLW glass insofar as plucing approximate limits on the cxicnt of teaction and to model alteration as a function of cavironmental conditions. It was also concluded that the laboratory tesiss involving the reaction of HLW glass with water vapor at high tempetalures can scrve to simulate the elfects of long-term subacrial alteration that would be expected for thesc giasses in a repository.

\section{RECOMMENDATIONS FOR FURTHER STUDY}

The scarch for a better scientific understanding of the dissolution of nalural glasses should continue by the employment of the three approaches utilized in previous studics:

- inquiry by careful observation of natural processes in the field;

situ; and. inquiry by physicochemical experimentation in the laboratory and in

- inquiry by theoresical modcling.

It is not expected that any one of these approaches can fully cxplain the details of a system or process. Nevertheless, scientific inquity by means of such a tri-pronged atrack gencrally excecds the sum of the individual componcnis in producing meaningful results. 


\section{FIELD STUDIES}

Two different types of ficld studies are proposed:

1) Search for well-constrained natural analogues. This work would place emphasis on the collection of well-constrained samples with respect to age, homogencity of the glass, constant composition of fluid with time, tolal immersion, etc. This probably can't be accomplished by a review of the literaturc, but will entail considerable ficld work and in all likelihood drilling activities For cxample, sample quenched Mows in Hawaii for datable carbon content as well as an eye towards constancy in fluid flow and composition over time, glass homogeneity, ctc.. Owing to the proposed composition of the waste glass, this study will focus primarily on natural basaltic glasses as they are similar in composition to that of the waste glass. It will be required to chemically analyze the unaltered glass, nuid, and the composition and relative amounts of alteration products. The latter will require considerable development work in analysis owing to the fact that present statc-of-the-an methods are generally nol capable of identifying phases in extremely fine-grained or cryptocrystalline matcrial.

It has ben proposed (W. L. Baurcier, pers. comm., 1988) that geothermal holes drilled near Kilauca could be studied with respect to natura! analogues for glass dissolution. The fluid phases have been collected and analyzed in some detail by Thomgs (1987), but relatively little has been done in characterizing the solid phases which include altered basaltic glass. Bottom holc temperatures range from $320-370^{\circ} \mathrm{C}$ and alteration minerals include zcolites, clays, chlorite, and cpidotc. Following charactcrization of the solid phases. Bourcier points out that geochemical modeling could be validated by correctly predicting the observed paragenesis. Bourcier also notes that there are some problems with the Kilauea site including the lack of age control on the lava flows and the inability to correlate fluid samples with specific rock horizons.

It has been proposed (H. F. Shaw, pers. comm., 1988) that the collection of glass formed by underground nuclear tests could prove useful. Some tests were performed below the water table and some have been subjected to water interaction over 20 years. There are three major drawbacks to this idea: (1) sampling would involve relatively expensive drilling costs, (2) the glass could be too rich in silica to be direcily compared to the proposed HLW glass composition, and (3) the thermal history is complex in that there was a high-temperalure period folluwing the detonation of the nuclear weapon followed by a cooling period and finally a period of ambient temperatures. Most of the glass alteration would have presumably taken place during the higher-temperature period. Nevertheless, we would know the composition of the flowing fluid would have been constant and that the temperature of the system has not changed after the glass cooled - putting some constraints on these samples where it might be difficult to do likewise for natural basaltic samples. In addition. radionuclide migration could be monitored.

It could also be useful to extend the work of previous workers in regards to field collections of medieval, man-made glasses. Samples would be sought out that vary in composition, age, and that werc subjected to varying environmental conditions. This work could provide a crucial time link from laboratory tests of a year or so duration to basalts that are hundred of thousands to millions of years old. 
2) Quantitatively evaluate the survival rates of natural glasses in the environment. I noted that a histogram of observations of 245 dalcd volcapic glasses in the western United States is exponential in shape with the vast majority of glasses being quitc young, less than 3 million years old (Ewing, 1979). If the following rather, broad assumptions are made:

different ages.

The observations are proportional to the actual amouns of glasses of

Glasses disappear solely by burial or dissolution.

- Devitrification is not a major destruction mechanism for glass owing to the very slow diffusion rates to form microcrystallites at low temperatures.

- Vulcanism and the amount of glasses produced has been constant over this time period in this region.

The decay curve of glass dissolution would represent a dissolution rutc for geologicalaveraged-over-time conditions for "average" glass compositions. Or, one could vicw this curve as representing the probability of finding glasses of certain ages, or the probability of glasses surviving for certain time periods. Dala to be collected to put this idea on firm footing would be the production and present abundance of volcanic glasses over the past 50-100 million ycars.

\section{EXPERIMENTAL, STUDIES}

Two broad types of experimental studies could augment and complement previous experiments on glass dissolution conducted over the past 50 years:

1) Experimental studies that provide quantitative information on the dependency of glass dissolution on the composition of the glass. A 1 present there are few well-constrained experiments regarding the dependency of glass dissolution on the composition of the glass. It may be that geochemical modeling will not be possiblc without such a data set owing to the fact that such compositional data will probably be required to build realistic theoretical models. In addition should the composition of the proposed HLW giass change markedly, compositional data will allow long-term predictions of glass durability for the new glass composition(s) without having to repeal experiments for each composition.

2) Experimental studies on the dissolution of natural basaltic glass. It will be required to conduct further hydrolhermal alteration experiments on unaltered natural basalic glass and 10 identify the composition, and relative amounts of alteration products as well as monitor the composition of the solution. These cxperiments are necessary to assess the suitability of accelcratcd (c.g.. higner temperature, high or low $\mathrm{pH}$, large water/glass ratios, high glass surface arcas, ctc.) tests in modeling long-term dissolution rates.

\section{THEORETICAL STUDIES}

Two broad arcas of theoretical studies are proposed:

1) Geochemical modeling. One approach to studying the dissolution of glass is to cxperimentally determine the rates of dissolution as a function of various 
parameters: $\mathrm{pH}$, temparature, aqueous silica concentration, ctc. Although this approach may be useful to guide theoretical modeling, it is clear that this approach cannot be used alone to make long-term predictions of glass dissolution rates. Large. multi-component geochemical systems arc simply not amenable to analysis based on a few variables. All variables, in general, must be considered simuliancously.

Improvements in conceptual models for glass dissolution must be made for any meaningful modeling computations. For example one model is that the early slages of glass dissolution is characterized by rapid dissolurion of alkalis from the surface onving to activated surfaces and a ready supply of the more soluble compon-nts of the glass at the surface. This is followed by the buildup of a palagonitic rind layei (diffusion controlled) until the rind thickness becomes constant and dissolition is then controlled by transpon through the rind. Transport across this rind becomes more difficult and glass dissolution rates decrease. Questions to be answered to substantiate this model includes:

- Is a constant thickness rind layer achieved with time observed in experiments or in natural glasses?

- Does the rind layer become increasingly impervious with lime?

- What is the interrelationship between diffusion in the glass and mass transport across the rind laycr?

- Is diffusion an important process in the rind layer, across the rind layer at later stages of dissolution maturity?

- Can the early gel-like rind layer be characterized thermodynamically?

It is clear that the rate of interaction between a glass and a fluid depend on scueral physical and chemical parameters. The composition of the glass and nuid, the surface area of the solid, the water-rock ratio, and the temperature and pressure are obvious candidates to consider regarding dissolution rates. Much has been made of the fact that glass is not a stable phase and is somewhat different froin other solids that are weathered on the carth's surface. In fact all igncous and metamorphic and most scdimentary rocks in the near crustal environment arc in discquilibrium with their surrounding cnvironment and thus are also not stable phases. It is thus conccivable that much is to be leamed regarding glass dissolution by looking at the wosk of others who have studied mineral-water reaclion rates (c.g., Wood and Walther, 1983).

In 1983. Walther and Wood contended that the rates of mineral dissolution at high Icmperature for virtually all mincrals from orthosilicates through tektosilicates dissolve with essentially the same rate constant under near-neutral conditions when the rate constants were normalized to gram-atoms of oxygen per square centimeter per second which translates to multiplying each molar rate by the number of oxygens per mole. For glasses we would have to determine how to normalize the experimental measured rates of dissolution. It is apparent that, in general, the rates of dissolution arc less for glasses that contain oxide components with a greater proportion of oxygen. For example silica-rich glasses dissolve more slowly that glasses rich in alkali or alkaline carth oxides. 
At $25^{\circ} \mathrm{C}$, Walther and Wood (1986) propose that there is a relationship between the reaction rate and the relative entropies per unit volume or gram atom of oxygen. It was observed that minerals $v^{\text {th }}$ high entropy per unit volume $\left(\mathrm{S}^{\circ} / \mathrm{V}^{\circ}\right)$ dissolve more rapidly than those with low entropy per unit volume. As above the sales were normalized to a constant gram atom of oxygen basis. Although the correlation observed by Walther and Wood was far from perfect, the approach may be uscrul in interpreting the dependency of glass dissolution rates on the composition of the glass. As interpreted by Walther and Wood. their correlation of reaction sates with entropies is based en the fact that dirferent silicates produce different concentrations of the activated surface complex and that the most unstable silicate (that with the greater critropy) produces the more abundant activated complexes. Thus the more unstable minerals will dissolve at higher rates than the more stable minerals because ahey produce greater coneentrations of aclivated complexes on the mineral surface. Glass components with lower entropies per volume, in general dissolve more slowly than those components with higher entropies per volume with a few exceptions (c.g.. MgO scerns "out of order").

A comparison of EQ3/6 (Wolery, 1979) calculations involving 91 day leach watcrs from SRL-165 glass and glass of basaltic composition indicaled gencral agreenent. The same components were chosen as those by Bourcicr (1988). Components were chosen similar to that of "hydration theory thermodynamic model" of Paul (1977), but picked so that they had the same coordination number of the metal as that in the glass. Metamorphic phases such as andalusite and wollasionite were thus included despite the fact that these phases are not expected phases to crystallize from melts of basaltic composition. In addition preliminary calculations were madc involving J-13 water and basaltic glass and SRL-165 glass at 90 and $150^{\circ} \mathrm{C}$ using Gt (C. Bethke, 1988). Again there was general agrecment between the types of glasses. In this case oxides were chosen as solid components. Despitc these encouraging exploratory calculations, there are problems to resolve in modeling glass dissolution which includes:

- How does onc choose components for the glass? Arc simple oxides as components realistic, or metamorphic phases? Perhaps CIPW normillive phases would be more realistic. Or phases that would be expected to crystallize out of glass of basaltic composition. It could be fruitful to look into followin: an approach similar to that used by modelers of high temperature crystallization from a mclt (c.g.. Ghiorso, 1987: Berman and Brown, 1987), but in this case reac!ing the glass with a Muid phase at lewer temperatures,

modeled? Are the chosen components part of a solid solution and if so how is it components?

How does one account for the differing rates of dissolution for these solid

- Ate there sufficient thermodynamic data available on the components in the glass, sccondary stable phases formed, and unstable gels formed?

2). Assessment, development, and use of theoretical methods for estimation and correlation of thermochemical data. Thcorcicat investigations that predict thermochemical systematics and propertics arc essentia! since the potential experimental test matrix is too prohibitively large to allow laboratory measurements to be made for all necded thermochemical dalia and also 
provide a means for estimating thermochemical properties where experiments are difricult or impossible to conduct. There is presently insufficient thermochemical data to allow comprehensive modeling of glass dissolution in nature or in the laboratory. Hence it is not presently possible to use geochemical modeling computer codes such as EQ3/6, Gt, or PATH, in predicting or estimating the long-term ditrability of the glass waste form.

Most of the thermodynamic data for common minstals presently used in geochemical computations are from the compilation by Helgeson ct at. (1978) and do not take into account recent experimental sesults. In addition Helgeson and coworkers used multipic linear regression in deriying their dataset which rcsults in a sensitivity to the order or path of data analysis. All experimental results involving a given phase therefore do not necessarily contribute to the refinement of the thermodynamic properties for that phase. Mathematical programming methods (Berman, el al. 1986) that extended the linear programming approach of Gordon (1973) have been used to update part of the thermodynamic data sct for minerals utilizing recent calorimetric and phase equiiibrium data. This new set of internally consistent thermodynamic data for mincrals (Berman et al., 1985; Berman. et al., 1986; Brown, pers. comm., 1988) differs in part from the earlier data set for minerals of Helgeson et al. (1978). There presently needs to be a careful evaluation of these data in order to select which thermodynamic data for minerals are to be used in modeling calculations.

It ii equally important to know the thermodynamic properties of aqueous species associated with rock-forming minerais and are commonly found in groundwaters as well as those of radionuclides in order to calculate solubilitics. As is the case with laboratory determinations of thermochemical propertics of minerals, the lest matrix to determine experimentally all the necessary thermochemical properties for species of interest is prohibitively large. It is therefore often necessary to rely on theoretical models to predict thermochemical properties in cases where data is lacking or difficult or impossible at this time to measure. The principle of corresponding states (c.g., Criss and Cobble, 1964) that Icpresents thermodynamic propertics at a given icmperature and pressure as linea functions of the corresponding properly at another temperature and pressure is very useful where therc is extensive experimental data set. Where such an extensive experimental datasct is lacking, applicarion of semiempirical clectrostatic/nonclectrostatic models and continuum theory to describe themodynamic properties can be employed (c.g., Helgeson, el al., 1981). Both approaches could be used to evaluatc recent experimental data and to refine the thermochemical parameters needed to carry out geochemical modeling computations. Evaluation of the data would in addition provide improvement in concepts as well as algorithms that represent fundamental parameters of aqueous species. 


\section{BIBLIOGRAPHY 1}

Aagaerd, P., and Helgeson, H. C., 1982, Thermodynamic and kinctic constraints on seaction rates among minerals and aqueous solutions. I. Theorctical considerations, Am. J. Sci., 282, p. 237-286. HQS.80517.2373.

Abrajano, Jr., T. A., and Bates, J. K., 1987, Transport and reaction kinetics :' the glass-solution interface region: results of tepository-driented leaching experiments, Mat. Kes. Sac. Symp. Proc., 44, p. 533-545. NNA.90125.0106.

Abrajano, Jr., T., Bates, J., Ebert, W., and Gerding, T., 1986, The effect of gamma radiction on groundwater chemistry related to the NNWSI repository sile, Lawrence Livermore National Laboratory Report. UCRL-15825, 12 p. HQS.880517.2375.

Adams, P. B., 1979, in, Int. Symp. Ceramics in Nuclear Waste Management, Chikalla, T. D. and Mendel, J. E., eds.. American Ceramic Jociety, Columbus, OH. p. 233-237. NNA.900306.0021.

Adams, P. B., 1984, Glass corrosion a record of the past? A prediclor of the future?, I. Non-Cryst. Solids, 67, p. 193-205. NNA.900215.0002.

Adiga, R. B., Akomer, E. P., and Clark, D. E., 1995, Effects of flow paramclers on the leaching of nuclear waste glass, Mat. Res. Soc. Symp. Proc., 4d, p. 45-54. NNA.900125.0107.

Ailin-Pyzik, 1. B., and Sommer, S. E., 1981, Microseale chemical effects of low temperalure alteration of DSDP basaltic glasses, J. Geophys. Res., 86, p. 9503-9510. NNA.9010306.0022.

Aincs, R. D. 1986, Estimates of radionuclide release from glass waste forms in a luff repository and the effects on regulatory carropliance, Lawrence Livermore National Lahoratory Report, UCRL93735, 12 p. HQS.8B0517.2377.

Aincs, R. D., 1986, Application of EQ316 modeling of nuctear waste glass behavior in a iuff repository, Lawfence Livermore National Laboratory Report, UCID-20895, 11 p. NNA.900215.0004.

Aines, R. D. 1987, Plan for glass waste form testing for NNWSt, Lawrence Livermore Nolional Laboratory Report. UCID-21190, 29 p. NNI.881209.0026.

Aines, R. D., Weed, H. C., and Bates, J. K., 1987, Hydrogen speciation in hydrated layers on nurlear waste glass, Mos. Res. Soc. Symp. Proc., 84, p. 547-558. NNA.900125.0108.

Allen, C. C. 1980. Icelandic subglactal volcanism: thermal and physical studics, J. Geol., 88, p. i08-117. NNA.900306.0023.

Allen, C. C., 1982, Stability and alcuration of naturally occuring low silica glassck: implications for the long $1 \mathrm{erm}$ stability of waste form glasses. in. Scientific Basis for Nuclear Waste Management, Lutce, W., ed., Elsevier, New York, p. 57-68. NNA.900215.0005.

\footnotetext{
1 This bibliograpty is more exlensive than normally would heve been prepased for a review of this nature. The resson for

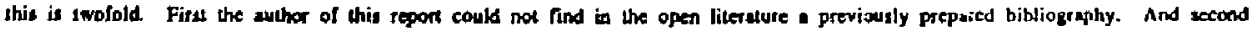

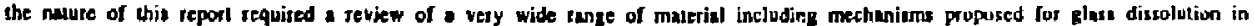
eneral; and, field, laboratory, and theoretical atudies of glass durability. The inest of incleding this bibliography in this repon is to povide other intesested workert - jurping off point for enuance into the literature.
} 
Allen, :- C., Gooding, J. L., Jercinovíc, M., and Keil, 1981, Altered basaltic glass: A terrestrial analog to the soil of mans, Jcarus, 45, p. 347-369. NNA.900306.0024.

Allen, C. C., Lane, D. L., Johnston, R. G., Marcy, A. D., and Adee, R. R., 1985, Hydrothermal sludies of simulated defense waste glass plus basalt, Mar. Res. Soc. Symp. Proc., 44, p. 451-458. NNA.900125.0109.

Alienhein, F. K., Lulze, W., Malow, G., 1981, The mechanism for hydrothermal leaching of glass and glass-ceramic nuclear waste forms, Mat. Res. Soc. Symp. Proc., 3, p. 32-38. NNA.900312.0143.

Ambrose, W. 1976. Intrinsic hydration rate dating of obsidian, in, Advances in Obsidian Glass Studies, Taylor, R. E., ed., Noyes Press, Park Ridge, NJ, p. 81-105. NNA.900405.0455.

Andrews, A. J., 1977, Low temperalure Tuid alteration of oceanic Layer 2 basalts, DSDP Leg 37. Can. J. Earth Sci., 14, p. 911-926. NNA.900306.0025.

Apled, M. J., and Adiga, R., 1985, The effect of groundwater flow on relcase rate hehavior of borosilicate glass, MaI. Res. Soc. Symp. Proc., 44, p. 163-170. HQS.880517.2379.

Amdt. I., and Haberle, F., 1973. Thermal expansion and glass transition temperalures of synthetic glasses of plagioclasc-like compositions, Contrib. Min. Petrol, 39, p. 175-183. NNA.900306.0026.

Amold, G. W. 1985, Ion implantation damege processes in nuclear waste glass and other silicate glasses, Mat. Res. Soc. Symp. Proc., 44, p. 617-622. NNA.900125.0110.

Bach, H., 1988, Estimation of the enthalpies of formation for leached subsurface layer materials from ion beam sputtering and analysis, J. Non-Cryst. Solids, 102, p. 43-49. NNA.900215.0007.

Bacon, C. R., 1977, High temperature heat content and heat capacity of silicate glasses: experimental decermination and a model for cilculation, Am. J. Sci., 277 , p. 109-183. NNA.900306.0272.

Baer, D. R., Pederson, L. R., and McVay, G. L., 1984, Glass reactivity in aquecus solutions, J. Vac. Sci. Technol., A2(2), p. 738-743. NNA,900215.0006.

Banba, T., Murakami, T., and Kimura, H., 1985, Moving boundary model for leaching of nuclear waste glass, Mal. Res. Sac. Symp. Proc., 44, p. 113-120. NNA.900125.0111.

Banks, H. H., 1972, Iron-rich saponite: additional data on samples dredged from the Mid-Alantic Ridge, 22N, Smilhsonian Contrib. Earsh Scl.,9, p. 39-42. NNA.900312.0144.

Baragar, W. R. A., Plant, A. G., Pringle, C. J., and Schau, M., 1977. Petrology and alteration of selected units of mid-atlantic ridge basalt: sampled fron sites 332 and 335, DSDP Leg 37, Can. J. Earth Sci.. 14, p. 837-874. NNA.900306.0027.

Barkatt, Aa., Barkatt, Al., Pehrsson, P. E., Szoke, P., and Macedo, P. B., 1981, Statc and dynamic lests for the chemical durability of nuclear waste glass, Nucl. Chem. Woste Monagement, 2, p. 15I164. NNA.900306,0028. 
Barkatt, At., Boulous, M, S., Barkatt, A., Scusınpour, W., Broomand, M. A., Maccdo., P. A., and O'Keefe. J. A., 1984, The chemical durability of secitites - A laboralory study and correlation with tong-term corrosion behavior, Geochim. Cosmochim. Acta, 48, p.363-372. NNA.900306.0029.

Barkatt, Aa., Gibson, B. C., and Brandys, M., 1985. A kinetic model of nuclear waste glass dissolution in flowing water environments, Mat. Res, Soc. Symp. Proc., 44, p. 223-236. HQS.880517.2385.

Barkatt, As., Macedo, P. B., Gibson, B. C., and Montrose, C. J., 1987, Morlclling of waste form performance and system release, Mas. Res. Soc. Symp. Proc., 44, p. 3-14. NivA.900125.0112.

Barkalt, Aa., Macedo, P. B., Sousanpour, W., Barkatt, Al., Boroomand, M. A., Fisher, C. F., Shirron, J. J.. Szpkc. P., and Rogers, V. L., 1983, The use of a flow test and a now model in cvaluating the durability of various nuclesr waste-form materials, Nucl. Chem. Waste Management, 4, p. 153-169. NNA.900306.0030.

Barkatt, Aa., Saad, E. E., Adiga, R., Sousanpour, W., and Barkatt, Al., 1986, Leaching of microteklitc glass compositions in seawater, Adv. Ceram., 20, p. 681. NNA.900320.0143.

Barkatt, Az., Simmons, J. H., and Macedo, P. B., 1981, Corro: ion mechunisms and chemical durability of glass media proposed for the fixation of radioactive wastes, Chemical Waste Management, 2, p. 3-23. NNA.900215.0008.

Barkath, Aa., Simnions, J. H., and Macedo, P. B., 1981, Evaluation of chemical stability of vitrification media for radioactive waste products, Phys. Chem. Glasses, 22, p. 73-85. NNA.900306.0031.

Barkatt, Aa.. Sousanpour. W.. Barkatl, Al., and Boroomand, M. A., 1984. Erfects of metals and melal oxides on the leaching of nucleas waste glass, Mas. Res. Soc. Symp. Proc., 26, p. 689-696. NNA.900215.0009.

Barkatt, Aa., Seusanpour, W., Barkatt, Al., Boroomand, M. A., and Maecdo, P., 1984, Leach behavior of SRL TDS-131 defense waste glass in watcr at high/low flow rates, Mat. Res. Sac. Symp. Proc., 26, p. 643-653. INNA.900215.0010.

Barrett. N. T.. Antonini, G. M., Thornley, F. R., Grcaves, G. N., and Manara. A., 1987. Structural changes around usanium at the surface of waste glasses caused by leaching. Mat. Res. Soc. Symp. Proc., 84, p. 571-576. NNA.900125.0113.

Bart, O. Aerne, E. T., Grauer, R., Linder, H., Z'Berg. D., ard Zwicky. H. U., 1985. Surface film charaeterization of corroded HLW glass specimens, Hal. Res. Soc. Symp. Proc., 44, p. 213-220. NNA.900125.0114.

Bartholomew, R. F., 1983, High-water containing glasses, J. Non-Cryst. Solids, 56, p. 331-342. NNA.900306.0032.

Bartholomew, R, F., Tiek, P. A., and Stookcy, S. D., 1980, Water glass reactions at elevated temperatures and pressures, J. Non-Cryst. Solids, 38/39, p. 637-642. NNA.900215.0012.

Bates, J. K. and Oerding. T. J., 1986, One-year resulls of the NNWSI unsaturated test procedure: SRL 165 glass cpplicalion, Argonne National Laboralory report, ANL-85-41, 78 p. NNA.870903.0081. 
Bates, J. K., and Gerding, T. J., 1985, NNWSI waste form performance test development, Mat. Res. Soc. Symp. Proc., 44, p. 295-302. NNA.900125.0115.

Bates, J. K., and Gerding. T. J., 1988, The performance of actinide-containing SRL 165 type glass in unsaturated conditions, Mat. Res. Soc. Symp. Proc., 112, p. 651-662. NNA.900306.0033.

Bates, J. K., Gerding, T. J., Abrajano, Jr., T. A., 1986, NNWSI waste form testing at Argonne No:ional Laboratary, Lawrence Livermore National Laboratory Report, UCRL-15801, 57 p. HQS.880517.2393.

Bales, J. K., Jardine, L. I., and Steindler, M. J., 1982, Hydratiol, aging of nuclear waste glass, Science, 218, p. 51-53. NNA.891101.0005.

Bates, J. K., Seitz, M. G., and Steindier, M. J., 1984. The relevance of vapor phase hydration aging to nuclear waste isolation, Nucl. Chem. Waste Management, 5, p. 63-73. NNA.900306.0034.

Batcs, J. K., and Steindler, M. J., 1983, Alteration of nuclear wasie glass by hydration, Mater. Res. Soc. Symp. Proc., 15, p. 83-90. NNA,900306,0035.

Batcs, J. K., Stcindler, M. J., Tani, B., and Purcell, F. J., 1985, The hydration alteration of a commercial nuclear waste glass, Chem. Geol., 51, p. 79-87. NNA.900306.0036.

Batcs. J. K., and Oversby. V. M., 1985. The behavior of actinide containing glasscs during gamma irradiation in a saturated tuff environment, Hat. Res. Soc. Symp. Proc. 14, p. 257-264. NNA.891101.0010.

Baucke, F. G. K., 1974, Investigation of surface layers, formed on glass electrode membranes in aqueous sotutions, by means of an ion sputtering technique. J. Non-Cryst. Solids, 14, p. 13-24. NNA.900306.0037.

Bazan. F., and Rcgo, J., 1985. Parametric testing of a DWPF borosilicate g'15s, Mat, Res, Soc. Symp. Proc., 44, p. 303-310. NNA.370407.0185.

Bcman, R. G. and Brown, T. H., 1987, Development of models for multicomponent melts: Analysis of synthetic systems, Rev. Mineralogy, 17, p. 405-442. NNA.900312.0145.

Bcrman, R. G., Brown, T. H., and Grecnwood, H. J., 1985, An internally-consistent thermodynamic data base for minerals in the system $\mathrm{Na}_{2} \mathrm{O}-\mathrm{X}_{2} \mathrm{O}-\mathrm{CaO}-\mathrm{MgO}_{8} \mathrm{FeO}-\mathrm{Fe}_{2} \mathrm{O}_{3}-\mathrm{Al}_{2} \mathrm{O}_{3}-\mathrm{SiO}_{2} \cdot \mathrm{TiO}_{2}-\mathrm{H}_{2} \mathrm{O}-\mathrm{CO}_{2}$ : Alomic Energy Canada Tech. Rpt. 377. 62 p. NNA.900312.0146.

Berman, R, G., Engi, M., Greenwood, H. J., and Brown, T. H., 1986, Derivation of internallyconsisten: thermodynamic dala by the technique of mathematical programming: a review with application to the system $\mathrm{MgO}_{3} \mathrm{SiO}_{2}-\mathrm{H}_{2} \mathrm{O}$, Jour. of Petrology. 27, p. 1331-1364. NNA.900306.0038.

Bibler, N. E., and Jantzen, C. M., 1987, Materials interactions relating 10 long-term geologic dispossl of nuclear waste glass, Mat. Res. Soc. Symp. Proc., 84. p. 47-66. NNA.900125.0116.

Bibler, N. E., and Jurgensen, A. R., 1988, Leaching Te-99 from SRP glass in simulated tuff and salt groundwaters, Mol. Res. Soc. Symp. Proc., 112, p. 585-594. NNA.900306.0039. 
Bihler, N. E., Wicks, O. O, and Oversby, V. M., 1985, Lesching Savannah River Plant nuclear waste glas: in a saturated tuff environment, Mat. Res. Soc. Symp. Proc., 44, p. $247-256$. NNA.900125.0117.

Bickford, D. F., and Janizen, C. M., 1984, Devitrification behavior of SRL deicnse waste glass, Mat. Res. Soc. Symp. Proc., 26, p. 557-565. HQS.880517.2400.

Bickford, D. F., and Pellaring, D. J., 1987, Large scale leach testing of DWPF canister scctions, Mat. Res. Soc. Symp. Proc., 84, p. 509.518. HQS.880517.2401.

Bidoglio, O., Offermann, P., De Plano, A., and Lazari, G. P., 1988, Influcnce of gruundwater composition on glast lenching and actinide speciation. Mat. Res. Soc. Symp. Proc., 112. p. 621-630. NNA.900306.0040.

Bischoff, J. L., and Dickton, F. W., 1975, Seawater-basalt interaction at $200^{\circ} \mathrm{C}$ and 500 bars: Implications for origin of sea-floor heavy-metal deposits and regulation of scawater chemistry. Earth Flanet. Sal. Lell., 25, p. 385-397. NNA.900306.0041.

Boksay, Z., Bouquel, O., and Dobos, S., 1967, Dilfusion processes in the surface Jaycr of glasses, Phys. Chem. Glasser. 8, p. 140-144. NWA.900306.0042.

Boksay. Z., Bouquec, G., and Dobos, S., 1968. The kinetics of the fomation of leached laycrs on glass iurfaces, Phys. Chem. Glasses, 9, p. 69.71. NNA.900215.0014.

Bonatti, E., 1965, Palagonite. hyaloclastites and the alteration of volcanic glass in the occan, $B u l l$. Volc., 28, p. 257-269. NNA.900306.0043.

Boulos, E. N., DePaula, R. P., El-Bayoumi, O. H., Lagakos, N., Macedo, P. B.. Moynihan, C. T.. and Rethson, S. M., 1980, Crystallization of nuclcar wasic disposal glass, Am. Ceram. Soc. Bull., 63. p. 496-501, NNA.900306.0044.

Brookins, D. G., 1987, Coupled processes at the Oklo natural reactor, in, Tsang, Chin-Fu, ed. Coupled Processes Associaled with Nuclear Waste Reposilories, p. 237-248. NNA.900430.0046.

Brutun, C. J.. 1988, Geochemical simulation of dissolution of West Valley and DWPF glasses in J-13 water at $90^{\circ} \mathrm{C}$, Mat. Res. Soc. Symp. Proc., 112, p. 607-620. NNA.891006.0181.

Bunker, B. F., 1987, Waste glnss lenching: chemistry and kinctics, Mat. Res. Soc. Symp. Proc, 84, p. 493-507. NNA.900125.0118.

Bunker, B. C. and Amold, O. W., 1983. The effect of solution pH and iron concentration on leaching of silicate glass, Mat. Res. Soc. Symp. Proc., 15, p. 151-158. NNA.900306.0045.

Bunker, B. C. Amold, G. W., Beauchamp, E. K., and Day. D. E., 1983, Mechanisms For alkali leaching in mixed Na-K silicate glases, Jour. Non-Cryst. Solids, 58, p. 295-322. NNA.900215.0015.

Bunker, B. C., Arnold, G. W., Day, D. E., and Bray, P. J., 1986, The effect of molecular siructure on borosilicate glass lcaching, Jour. Non-Cryst. Solids, 87, p. 226-253. NNA.900215.0016.

Bunker. B. C., Headly. T. J., and Douglas, D. C., 1984, Gel structures in alkali silicate glass, Har. Res. Soc. Symp., 32. p. 41. NNA.900306.0046.

Bunker, B. C, Tallant, D, R., Headley, T, I., Turner, G. L., and Kirkpatrick. R. J., 1988. The structure of leached borosilicate glas, , Phys. Chem. Glasses, 29, no. 3. p. 106. NNA.900215.0017. 
Bycrly, G. K., and Sinton, J. M., 1979, Compositional trends in natural basaltic glasses from Decp Sea Drilling Project holes $417 D$ and 418A, in, Initial Reports of the Deep Sea Drilling Project 53. Donnclly, T. et al., cds,. U. S. Printing Office, Washington, D.C.. p. 957.971. NNA.900315.0281.

Byers, C. D., Jercinovic, M. J., and Ewing, R. C., 1987, A study of natural glass analogues as applied to alleration of nuclear waste glass, Argonne Nalional Laboratory, ANL-86-46 (or NUREG/CR4842), 150 n. NNA.900215.0018.

Byers, C. D., Jercinovic, M. J., Ewing. R. C., and Kcil, K., 1987. Basalt glass: an analogue for the cvaluation of the long-term stability of nuclear waste form borosilicate glasses, Mat. Res. Soc. Symp. Proc., 44, p. 583-590. NNA.900125.0119.

Carmichacl, I. S. E., Nicholls, J., Spera, F. J., Wood, B. J., and Nelson, S. A., 1977, High-temperalure properlics of silicate liquids: applications to the equilibration and ascent of basic magma, Phil. Trans. Roy. Soc. Lond., A286, P. 373-431. NNA.900306.0047.

Caurel, J., Bcaufort, D., and Vemaz, E. Y., 1988. Mineral phase identification along two profiles from the LWR French reference glass: Use of an $x$-tay position sensitive detector, Mas. Res. Soc. Symp. Proc., 112, p. 663-672. NNA.900306.0048.

Chick, L, A., and Pederson, L. R., 1984, The relationship between reaction layer thickness and leach rales for nuclear waste glasses, Mat. Res. Soc. Symp. Proc., 26, p. 635-642. NNA.900215.0019.

Christensen, H. Hermansson, H. P., Clark, D, E., and Werme, L, 1984, Surface reactions occurring on simulatcd nuclear waste glass immersed in aqueous solptions containing bentonitc. granite, and stainless steel corrosion products, in, Advances in Ceramics 8. Nuclear Waste Management, Wicks, G. C. and Ross. W. A., eds., The Amcrican Ceramic Socjely, Columbus. Ohio. p. 346-357. NNA.900315.0282.

Clark. D. E. and Hench, L. L., 1983, Theory of corrosion of alkali-borosilicate glass, Mat, Res. Soc. Symp. Proc., 15, p. i13-124. NNA.900306.0049.

Clement, S. C., and Ribbe, P. H., 1973, New locality, formula, and proposed structure for reyerite, Am. Mineral. 58, p. \$17-522. NNA.900306.0051.

Clark, D. E. and Hench, L. L., 1982, An overview of the physical characterization of leached surfaces, Nucl. Chem, Waste Management, 2, p. 93-101. NNA.900306.0050.

Colcs, D. G., Simonson, S, A., Thomas, L. E., Schramke, J, A., and McKinlcy, S. G., 1985, Investigation of the hydrothermal interaction of ${ }^{99} \mathrm{Tc}$-doped glass with basalt repository nuclear waste package components, hial. Res. Sor. Symp. Proc., 44, p. 323-332. NNA.900125.0120.

Conradt, R., Roggendorf, H., and Scholzc, H., 1985. A contribution to the moldelling of the corrosion process Jor HLW glasses, Mot. Res. Soc. Symp. Proc., A4, p. 155-162. NNA.900125.0121.

Conradil. R., Roggendorf. H., and Scholze. H., 1985, Investigations on the role of surface layers in HLW glass leaching, Mat. Res. Soc. Symp. Proc., 50. p. 203-210. NNA.900306.0052.

Cowan, R., and Ewing, R. C., 1986, Alicration products of basaltic glass, Hanauma Bay. Oahu, Haw'sii, in. Microbeom Analysis - 1986. Romig, A. D., and Chambers, W, F., eds., San Francisco Prcss, San Francisco, p. 131-134. NNA.900215.0020. 
Crisg, C. M., and Cobble, J. W., 1964, The thermodynamic propertics of high-temperature aqueous solutions, J. Am. Chem. Soc., 86, p. 5385-5393. NNA.900306.0053.

Crovisier, J. L., and Eb-thart, J. P., 1985, Apports de la microscopie electronique a l'etude des couches d'alteration formees a la surface des verres, $J$. Microse. Spectrosc. Electron., 10, p. 171180. NNA.900312.0148.

Crovisies, J. L., Eberhart, J. P., Thomassin, J. H., Juteau, T., Touray, J. C., and Ehret, G., 1982, Interaction eau de mer-verre baraltique $50^{\circ} \mathrm{C}$. Formation d'un hydroxy-earbonate cl de produits silicates amorphes (Al, $\mathrm{Mg}$ ) et mal cristallises (Ai, Fe, Mg). Etude en microscopic electronique et par spectromietric des photoelectrons (E.S.C.A.), C. R. Acad. Sci., 294, Str. II, p. 989-993. NYNA.900306.0054.

Crovisier, J. L., Fritz, B., Grambow, B., and Eberhart, J. P., 1985, Diszelution of basaltic glass in seawater Experiments and thermodynamic modelling. in. Scientlfic Basis for Nuctear Waste Management IX, Werme, L., ed., p. 273-280. NNA.900:569055.

Crovisier, J. L., and Honnorez, 1988, Nuclear waste under glass, reconsidered, EOS Trans. AGU,69. p. 628. NNA.900306.0056.

Crovisier, J. L., Ho :nores, J., and Eberhart, J. P., 1987, Dissolution of basalic glass in scawater: Mechanism and rate, Geochim. Cosmochim. Acta, 51, p. 2977-2990. NNA.900215.0021.

Crovisier, J. L., Thomassin, J. H., Juteau, T., Eberhart, J. B., Touray, J. C., and Baillif, P., 1983, Experimental seawater-basaltic glass interaction at $50^{\circ} \mathrm{C}$ : Study of early developed phases by electron microscopy and x-ray photoclectron spectrometry, Geachim. Cosmochim. Acta, 47. p. 377 . 387. NNA.900306.0057.

Dibble, W. E., and Tiller. W. A., 1981, Kinetic mociel of zeviite paragenesis in luffarcous sediments, Cloys Clay Mins., 29, p. 323-330. NNA.870406.0093.

Dibble, W. E., and Tiller, W. A. 1981, Non-equilibrium watcr rosk interactions 1. Model for interfact-controlled reactions, Geochim. Cosmochim. Acta, 45, p. 79-92. NNA.900306.0058.

Dickin, A. P., 1981, Hydrothermal leaching of rhyolite glass in the environment has implications for nuclear waste disposal, Nature, 294, p. 342-345. NNA.900215.0022.

Donnelly. T.. et al., 1975, Intial Reports of the Deep Sea :Jilling Project 51-53, U. S. Government Printing Office, Washisgton, D. C., p. 1613. NNA.900315.0283.

Doremus, R. H., 1979. Chemical durability of glass, in, Treatise on Materials Science and Technology 17. Tomozawa. M. and Doremus, R. G., eds., Academic Press, Ncw York, p. 41-69. NNA 900306.0059 .

Doremus, R. H, 1983, Diffusion controlled reaction of water with glass, J. Non-Cryst. Solids, 55, p. 143.147. NNA.900306.0060.

Doremus, R. H., Mehrotra, Y., Lanford, W. A., and Burman, C., 1933, Reaction of water with glass: Influence of a transformed surface layer, J. Mater. Sclence, 18, p. 612-622. NNA.900215.0023.

Dran, J-C. Langevin, Y. Doorhyec, E. and Petir. J-C., 1987, Modelling of the dissolution of silicate glasses by a montc-carlo code (ETCH), Mal. Res. Soc. Symp. Prac. 84. p. 559-569. NNA.900215.0024. 
Dran, J-C., Petit, J.-C, and Brousse, C., 1986, Mechanisin of aqueous dissolution of silicate glasses yielded by fission tracks Nature, 319, p. 485-497. NNA.900312.0150.

Dubrovo, S. K., and Schmiat, Yu. A., 1953, Bull. Acad. Sci. USSR. Div. Chem. Sci., 403, p. 535. NNA.900405.0456.

Ebert. W. L., Bates, J. K., Gerding, T. J., and Van Konynenburg, R. A., 1987, The effects of gamma radiation on groundwater chemistry and glass reaction in a saturated tuff envitonment, Mar. Res. Soc. Symp. Proc., 84, p. 613-622. NNA.89212.0005.

El-Shamy, T. M., Lewine, J., and Douglas, R. W., 1972, The dependence on sie pH of the decomposition of glasses by aqueous solutions, Glass Tech., 13, p. 81. NNA.900306.0061.

Ethridge, E. C., Clark, D. E., and Hench, L. L., 1979, Eifizass of glass surface arca to solution volume ratio on glass conosion, Phys. Chem. Glasses, 20, p. 35-40. NNA.900306.0062.

Ewing, R. C., 1978, Natural glasses; analogues for radioactive waste fcrms, in, Scientific Basis for Nuclear Wasie Management, McCarthy, G. J., ed., Plenum, New York, p. 57-68. NNA.900215.0025.

Ewing, R. C., and Haaker, R. F., 1979, Natural glasses: analogues for radioactive waste forms: Batteile PNL Repo:t 2776/UC-70, 71 p. NNA.900315.0277.

Exving, R. C., and Jercinovic, M. J., 1987, Natural Analogues: their application to the prediction of the Jong-1erm bchavior of nuclear waste forms, Mat. Res. Soc. Symp. Proc.. 84, p. 67-83. NNA.900215.0026.

Feng, X, and Barkatl, A., 1987, Effects of aqueous phase composition on the leach behavior of nuclear waste glasses, Mat. Res. Soc. Symp. Proc., 84, p. 519-531. NNA,960215,0027.

Feng, X., and Barkatt, A., 1988, Structural thermodynamic me... for the durability and viscosity of nuclear wasle glass, Mat. Res. Sor. Symp., 112, p. 543-55.4. NNA.900306.0063.

Feng, X., Barkalt, A., and Jiang, T., 1988, Systematic composition studies on the durability of waste glass WV205, Mat. ñes. Soc. Symp. Proc., 112, p. 673-684. NNA.900306.0064.

Flintofr, J. F., and Harker, A. B., 1985, Detailed processes of surface layer formation in borosilicatc waste glass dissolution, Mat. Res. Soc. Syms. Proc.. 44, p. 147-154. NNA.900215.0028.

Freude, E., Graminw, B., Lutze, W., Rabe, H., and Ewing. R. C., Long-term release from high-level waste glass - part IV: the effect of ieaching mechanism, Mat. Res. Soc. Symp. Proc.. 44, p. 99-106. HQS.880517.2439.

Fricdman, 1., and Smith, R. L., 1960, A new dating method using obsidian - Pan 1. The development of the method, Am. Antlquily, 25, p. 476-522. NNA.900312.0132.

Fricdman, 1., Smith, R. L., and Long, W. D., 1966, Hydration of natural glass and formation of perlite, Geol. Soc. Am. Bull., 77, p. 323-328. NNA.900306.0065.

Fricdman, I., and Long, W., 1976, Hydration rate of obsidian, Science, 191, p, 347-352. NNA,900306,0066.

Fricdman, I., and Trembour, F. W., 1978, Obsidian: the dating stone, Amer. Sci., 66, p. 44-51. NNA.900306.0067. 
Fumes, H, 1974. Volume relations between palagonile and authigenic minerals in hyaloclastilcs and it bearing on the rate of palagonitization, Bull. Volc. 38, p. 173.186. NNA.900312.0153.

Furnes, H., 1975, Experimtental palagonitization of basaltic glasses of varied composition, Contrib. Mineral. Petrol. 50, p. 105-113. NNA.900215.0029.

Furnes, H., 1978, Element mobility during palagonitization of a subglacial hyaloclastilc in Iceland, Chem. Geol., 22, p. 249-264. NNA,900306.0068.

Furnes, H., 1980, Chemical changes during palagonitization of an alkaline olivine basaltic hyaloclastite, Santa Maria, Azores, N. Jahr. Mineral. Abh., 138, p. 14-30. NNA.900315.0284.

Furnes, H., 1984, Chemical changes during progressive subaerial palagonitization of subglacial olivine tholeite hyaloclastite: A microprobe study, Chem. Geol., 43, p. 271-285. NNA.900215.0030.

Furnes, H., and El-Anbaswy, M. I. H., 1980, Chemical changes and mineral formation during palagonitization of a basanile hyaloclastite, Gran Canaria, Canary Islands, Neues Jahrbuch, 139, p. 279-302. NNA.900315.0285.

Garland, J. A., and White, W. B., 1985, Delermination of early stages of glass dissolution by pH titration, Mat. Res. Soc. Symp. Proc.. 44, p. 81-88. NNA.900215.0031.

Garrels, R. M., and Christ, C. L., 1965, Solutions, Minerals and Equilibria, Harper and Row, New York, p. i-v. NNA.900315.0286.

Garlick, G. D., and Dymond, J. R., 1970, Oxygen isotope exchange between volcanic matcrials and ocean water, Geol. Soc. Amer. Bull., 81, p. 2137-2141. NNA.900306.0069.

Geptner, A. R., 1978. Palagonite and the process of palagonitization, Liloligiya i Poliznye Iskopaemye, 5, p. 113-130 (in Russian). NNA.900312.0154.

Ghiorso, M. S., 1987, Modeling magmatic systems: Thermodynamic Relations, Kev. Mineralogy, 17. p. 443-466. NNA.900312.0155.

Gignac, L. M., Altstetter, C. J., and Brown, S. D., 1985, A nuclear reaclion analysís technique to determine the penetration of hydrogenic species into glasses exposed to leaching solutions, Mat. Res. Sac. Symp. Proc., 44, p. 107-112. NNA.900215.0032.

Glass, B. P., 1972, Bottle-green microtektiles, J. Geophys. Res., 77, p. 7057-7064. NNA.900215.0033.

Slass, B. P., 1982, Solution of naturally occurring glasses in the geological environment. NASA Contract. Rep. 170518, NASA/GSFC, Grecnbeit. Md. NNA.900312.0156.

Gordon, T. M., 1973, Determination of internally consistent thermodynamic data from phase equilibrium experiments, J. Geol., 81, p. 199-208. NNA.900306.0070.

Grambow, B., 1982, The role of metal jon solubility in leaching of nuclear waste glasses, Mat. Res. Soc, Symp. Proc., 11, p. 93-102. NNA.900306.0071. 
Grambow, G., 1984, Geochemicas modeling of the reaction between glass and aqueous solution, in, Advances in Ceramics Proc. Amer. Ceram. Soc. Symp. 85th, Wicks, G. G., and Ross, A., eds., 8, p. 474-481. NNA.900315.0287.

Grambow, B. 1984, Ein physikalischemiches Modell fur den Mechanismus der Glaskorrosion-unter besonderer Berucksichtigung simulierter radioaktiver Abfallglaser, Theses, Freien Universitat Berlin, 255 p. NNA.900215.0034.

Grambow, B., 1985, A general rate equation for nuclear waste glass corrosion, Maf. Res. Soc. Symp. Proc., 44, p. 15-27. HQS.880517.2447.

Gramt.ow. B., 1987, Nuclear waste dissolution: mechanism, model, and application, ISS Project Technical Report-87-02, Swedish Nuclear Fucl and Waste Management Co., 112 p. NNA.900215.0035.

Grambow, B., Jercinovic, B. J., Ewing, R. C., and Byers, C. D., 1985, Weathered basalt glass: a nalural analogue for the effects of reaction progress on nuclear wate glass alteration, Mat. Res. Soc. Symp. Proc., 50, p. 263-272. NNA.900306.0072.

Grambow, B., Lulze, W., Ewing, R. C., and Werme, L. O., 1988, Performance assessment of glass as a long-term barrier to the selease of radionuclides into the environment, Mat. Res. Soc. Symp. Proc., 112. p. 531-542. NNA.900306.0073.

Grambow, B., and Strachan, D. M., 1984, Leach testing of waste glasses under near-saturation conditjons, Mar. Res. Soc. Symp. Proc., 26, p. 623-634. NivA.870406.0329.

Grambow, B., and Strachan, D. M., 1988, A comparison of the performance of nuclear waste glasses by modeling, Mas. Res. Soc. Symp. Proc., 112, p. 713-724. NNA.900215.0036.

Haaker, R., Malow, G., and Offermann, P., 1985. The cffect of phase formation on glass leaching, Mas. Res, Symp. Proc., 44, p. 121-128. NNA.900215,0037.

Harvcy, K. B., and Litke, C. D., 1984, Madel for leaching behavior of aluminosilicate glasses developed as matrices for immobilizing high-level wastes, J. Am. Cer. Soc., 67, p. 553-61. NNA.900306.0074.

Harvey, K. B., Litke, C. D., and Boasc, C. A., 1986, The dissolution of a simple glass. Part 1. Initial model and application to an open glass/water system, Phys, Chem. Glasses, 27, p. 15-21. NNA.900306.0075.

Hawkins, D. B., and Roy, R., 1963, Experimental hydrothermal studies on rock alteration and clay mineral formation, Geochim. Cosmochim. Acta, 27, p. 1047-1054. NNA.900306.0078.

Hay, R. L., 1966, Zcolitce and zcolitic reactions in sedimentary tocks, Geol. Soc. Am. Special Paper 85. 130 p. NNA.900315.0288.

Hay. R. L., and lijima, A., 1968a, Pctrology of palagonitc uff's of Koko Craters, Oahu, Hawaii, Contrib. Mineral. Petrol., 17, p. 141-154. NNA.900306.0076.

Hay. R. L., and lijima, A., 1968b, Nature and origin of palagonite luffs of the Honolulu Group on Oahu, Hawaii, Geol. Soc. Am. Mem. 116, p. 331-376. NNA.900312.0157.

Hay, R. L., and Jones, B. F., 1972, Weathering of basaltic tephra on the island of Hawaii, Geol. Soc. Am. Buli., 83, p. 317-332. NNA.900306.0077. 
Helgeson, H. C., 1971, Kinetics of mass transfer among silicates and aqueous solutions, Geochim. Cosmochim. AcIa, 35. p. 421-469. NNA.900306.0079.

Helgeson, H. C., Delany, J. M., Nesbilt, H. W., and Bird, D. K., 1978, Summary and critique of the thermodynamic properties of the rock-forming minerals, Am. Jour. Sci.. $278 \mathrm{~A}$, p. 1-228. HQS.880517.2457.

Helgeson, H. C., Kirkham, D. H., and Flowers, G. C., 1981. Theorctical prediction of aqueous electrolytes at high pressures and temperaturcs: IV. Calculalion of activily coefficients, osmolic coefficients, and apparent molal and standard and rclative partial molal propertics to $600^{\circ} \mathrm{C}$ and 5 kb, Am. Jour. Sci., 281, p. 1249-1516. NNA.891006.0200.

Hench, L. L., 1975, Characterization of glass corrosion and durability, J. Non-Cryst. Solids, 19, p. 91-109. NNA.900306,00B0.

Hench, L. L. and Clark, D. E., 1978, Physical chemistry of glass surfaces, J. Non-cryst. Solids, 28. p. 83-105. NNA.900306.0081.

Hodder, A. P. W., 1984, Effect of composition on hydration kinetics in volcanic glasses: Implications for dating, J. Colloid Interface Sel., 103, p. 45-49. NNA.900306.0082.

Honnorez, J., 1969. La palagonitisation. Un aspect du volcanisme sous marin: l'alteration du verre basique de Palagonia (Sicile). These Sci. Nat. Univ. libre Bruxclles, 131 p. NNA.9010320.0144.

Honorez, J., 1984, Feneration of phillipsites by palagonitization of basaltic glass in sea water and the origin of K-rich decp-sea sediments, in, Natural Zeolites: Occurrence, Properties and Use. Sand, L. B., and Mumpion, F. A., eds., Pergamon Press, OxSord, p. 245.258. NNA.9100306.10083.

Houser, C. $A_{+}$and Pantano, C. G., 1985, Early stages of film formation during the leaching of radioactive waste glasses. Mat. Res. Soc. Symp. Proc., 44. p. 205-212. NNA.900215.0038.

lijima, A., and Harada, K., 1969, Authigenic zeolites in zealitic palagonite tuifs on Oahu, Hawaii, Am. Min.. 54, p. 182-197. NNA.900306.0084.

IJer, R. K.. 1955. Colloid Chemistry of Silice and Silicates, Cornell University Press, Ithaca, NY, p. $v-x i i$; 301-324. NNA.900320.0145.

Isard, J. O., AlInatt, A. R., and Melling, P. J., 1982. An improved model of glass dissolution, Phys. Chem. Glass, 23, p. 185 . NNA.900215.0039.

Jacquet-Francillon, N., Pacaud, F., and Qucille. 198:. An atucmpt to asscss the long-icrm crystallization rate of nuclear waste glasscs, Mat. Res. Soc. Symp. Proc., 11, p. 249-259. NNA.900306.0085.

Jakobsson, S. B., 1972, On the consolidation and palagonitization of the tephra of the Surtscy Volcanic Island, Iceland, Surtsey Res. Progr. Rep. VI, p. 121-128. NNA.900312.0159.

Jakobsson, S. P., 19-2, Environmental factors controlling the palagonitization of the Surtsey tcphra, Iceland, Bull. Geol. Soc. Denmark, 27. p. 91-105. NNA.900312.0158.

Jakobsion, S. P., and Moore, J. G., 1986. Hydrothermal minerals and alterution rutes at Sursey Volcano, Iceland, Geol. Soc. Am. Bull., 97, p. 648-659. NNA.900306.0086. 
Jantzen, C. M., 1984, Effects of Eh (Oxidation potential) on borosilicalc waste glass durability, in, Advances if Ceramics 8. Wicks, G. G. and Ross, W. A., eds., The American Ceramic Society, Columbus, OH, p. 385-393. NNA.900315.0290.

Janizen. C. M., 1986, Prediction of nuclear waste glass durability from natural analogs, Advances in Ceramics, 20, p. 703-712. NNA.900215.0040.

Jantzen, C M., 1988, Pourbaix diagram for the prediction of waste glass durability in geologic cnvironments, Mal. Res. Soc. Symp. Proc. 112, p. 519-530. NNA.900215.00^1.

Jantzen, C. M., 1988. Nuclear waste glass durability: 1. Predicling environmental responsc from thermodynamic (Pourbaix) diagrams, presented at the 89ih Ameriean Ceramic Socicty Mccting, Piltsburgh, PA, ms. NNA.900215.0042.

Jantzen, C. M., and Bibler, N. E., 1985, The sole of groundwater oxidation potential and radiolysis on waste glass performance in crystalline repository environments, Mar. Res. Soc. Symp. Proc., 50, p. 219-230. NNA.900215.0043.

Jantzen, C. M., and Bickford, D. F., 1985, Leaching of devilrified glass containing simulated SRP nuelear waste. Mat. Res. Soc. Symp. Proc., 44, p. 135-146. NNA.900215.0044.

Jantzen, C. M., Bickford, D. F., and Karraker. Time-temperature-transformation kinctics in SRL waste glass, in, Advances in Ceramics 8 , Wieks, G. G. and Ross, W. A., eds., The American Ceramic Socicty, Columbus, OH, p. 30-38. NNA.900315.0289.

Jantzen, C. M., and Plodinec, M. J., 1984, Thermodynamic model of natural, medin,val, and nuclear waste glass durability, J. Non-Cryss. Solids, 67, p. 207-223. NNA.900215.0045.

Jantzen, C. M., and Wicks. G. G., 1985. Control of oxidation potertial for basalt repsitory simulation tcsts, Mat. Res. Soc. Symp. Proc., 44, p. 29-35. NNA.900215.0046.

Jercinovic. M. J. and Ewing. R. C.. 1987. Basalic glasses from Iceland and the decp sea: Naiural analogucs to borosilicale nuclear wasie-form glass, JSS ljoint Japancse (CR:EP). Swiss (NAGRA), Swedish (SKB) project managed by Swedish Nuclear Fucl and Waste Management Co.J Technical Report 88-01, 221 p. NNA.900215.0045.

Jercinovic, M. J., Ewing, R. C., and Bycrs, C. D., 1987, Alteration products of hasalt glass from the Frenchman Springs Flow, Wantapum Basalts. Hanford. Washington, in, Advances in Ceramics 20: Nuclear Wasie Management 11 . The American Ceramic Socicly, Columbus, OH, p. 671-679. NNA.900320.0151.

JSS. 1987, Eroerimental and modelling studies of IILW glass dissolution in reposirory envirorments, Jss Joint Japanese (CRIEP), Swiss (NAGRA), Swedish (SKB) project managed by Swetish Nuclear Fucl and Waste Management Co.] Technical Repont 37-01. NNA.900215.0048.

Sulcau. T., Noack, Y., Whitechureh, H., and Courtois, C., 1980, Mineralogy and geochemistry of al'cration producls in Holes 417A and 417D basement samples (DSDP Leg 51). Inil. Rept. DSDP LI. LII, LIJI, part 2, p. 1273-1297. NNA.900430.0051.

Keith, T, E. C., and Staples, L. W., 1985, Zeolitcs in Eocenc basaltic pillow lavas of the Silctz River Volcanics, Cenital Coast Range, Oregon, Clays Clay Min., 33, p. 135-144. NNA.900306.0687. 
Kim, J. I., Treiber, W., Lierae, Ch., and Offerman, P., 1985, Solubility and colloid gencration of plutonium from leaching of a HLW glass in salt solutions, Mat. Res. Soc. Symp. Proc., 44, p. 359368. NNA.900215.0049.

Kohyama, N., Shimoda, S., and Sudo. T., 1985, Iron-rich saponite (feirous and ferric forms), Clays Clay Mins., 21, p. 229-237. NNA.900312.0161.

Krisumannsdottir, H., 1976, Types of clay minerals in hydrothermall altered basalic rocks, Reykjanes, Iceland, Jokull, 26. p. 30-39. NNA.900315,0291.

Kristmannsdottir, H., 1978, Alteration of basaltic rocks by hydrathermal activity at $100-300^{\circ} \mathrm{C}$, in. International Clay Conference, Developments in Sedimentology 27, Morlland, M. M., and Farmer, V. C., eds., Elsevier, New York, p. 359-367. NNA.900315.0292.

Kuhn, W, L. and Pelers, R. D., 1983, Leach models for a commercial nuclear waste glass. Mat. Rex. Soc. Symp. Proc., 15. p. 167-174. NNA.900306.0088.

Laidler, K. J., 1965, Chemical Kinclics, McGraw-Hill, New York, p. vii-ix, 542-566. NNA.900315.0293.

Lanford, W. A., Davis, K., Lamarche, P., Lauresen, T., Groleu, R., and Doremus, R. H., Hydration of soda-lime glass, J. Non-Cryst, Solids, 33, p. 249-266. NNA.900306.0089.

Lanza, F., and Ronsecco, 1982. Influcnec of a backfilling material on borosilicate glass leaching, in, Scientific Basis for Nuclear Waste Management V. Lutze, W., ed., North Holland, New York, p. 173180. NNA. 900306.0090 .

Lanza. F., Conradt, R., Hall, A. R., Malow, G., Troecllier, P., Van Iseghem, P., 1985, Mcchanisms of leaching and corrosion of vitrilied radioactive wastc forms, in, Radioactive Waste Management and Disposal: Proceedings of the Second Europeart Community Conference, Luxcmbourg. Simun, R., ed., Cambridge University Press. NNA.900315.0294.

Lanza, F., Manara, A., Mammarella, L., Blasi, P., and Ceccone, G., 1988, Borosilicalc liLW glass leaching in silica saturated solution, Mot. Res. Soc. Symp. Proc., 112 , p. 685-692. NNA.900306.0091.

Lasaga, A. C., 1984, Chemical kinctics of water-rock interactions, J. Geophysical Res., 89, p. 40094025. NNA.900216.0060.

Lasaga, A. C., and Kirkpatrick, R. J., 1981. Kinetics of Geochemical Processes, Reviews in Mineralogy.8, Mineralogical Society of America, p. i, vii-x. NNA.900430.004i..

Lec, Cheng-Tsin., 1986, Surface and solution chemistry of glass/water interactions, Unpub. Ph.D. disscrtation, Universily of Florida, 274 p. NNA.900216.0080.

Lec. C. T., and Clark, D. E., 1985, Elcctrokinelics, adsorplion and calloid study of simulated nuclear waste glasses leached in aqueous solutions, Mat. Res. Symp. Proc., 44. p. 221-228. NNA. 900215.0050 .

t.chman, R. L., and Kuchinski, F. A., 1985, The effect of various lead species on the leaching bihavior of borosilicate waste glass, Mal. Res. Soc. Symp. Proc., 44, p. 179-186. NNA.900215.0051. 
Lewis, R. A, and Scgalf, R. L,. Pressure dependence of glass dissolution and nuclear waste disposal, Nature, 299, p. 140-141. NNA.900312.0162.

Lindqvist, K., and Laitakari, J., I980, Glass and amygdules in Precambrian diabases from Orivesi, southem Finland. Geol. Soc. Findland Bull., 52, p. 221-229. NNA.905405.0458.

Lutzc. W.. Malow. G., Ewing, R. C., Jercinovic. M. J., and Keil, K.. 1985, Allcration of basall glasses: implications for modelling the long-term stability of nuclear waste glasses, Nature, 314, p. 252255. NNA.900215.0052.

Lutze, W., Muller, R., and Montserrat, W., 1988. Chemical corrosion of cogema glass R7T7 in high saline brines, Mat. Res. Soc. Symp. Proc., 112, p. 575-584. NNA.900306.0092.

Lu'zc, W., and Schubert, P., 1988, Chemical corrosion of lead-iron phosphate glass, Mat. Res. Soc. Symp. Proc., 112, p. 641-650. NNA.900306.0093.

Luyendyk, B. P., ct al., 1978, Initial Reports of the Duep Sea Drilling Project 49, U. 3. Govemment Printing Orfice. Washington, D. C., p. 1020. NNA.900315.0295.

Machiels, A. J, and Pescatorc. C., 1983, The functional dependence of leaching on the surface areato-solution volume ratio, Mar. Res. Soc. Symp. Proc., 15, p. 209-216. NNA.900306.0094.

Maggs, W. W., 1988, Mg may protect waste under glass, EOS Trans. $A G U, 69$, p. 49. NNA.900312.0163.

Malow, G., Lutze, W, and Ewing, R. C., 1984, Alteration effects and leach rates of basaltic glasses: implications for the long-term stability of nuclear waste form borosilicate glasses, J. Non Cryst. Solids, 67. p. 305-322. NNA.900215.0053.

Manara, A., Lanza, F., Ceccone, G., Calla Mea, G., and Salvagno, G., 1985. Application of XPS and nuclear technique to the study of the gel lavers formed under different redox conditions on Jcached glasses, Mal. Res. Soc. Symp. Proc., 44, p. 63-71. NNA.900215.0054.

Mark, T. D., and Ritter, W., 1987. Radiation damage and its anncaling in sodium silica glass, Mar. Res. Soc. Symp. Proc., 84, p. 659-669. NNA.900215.0055.

Mark. T. D.. and Walder. G., 1988. Annealing and leaching studics with natural and artificial cbsidian glass, Res. Soc. Symp. Proc., 112, p, 693-702. NNA.900306.0095.

Marshalt, R. R., 1961, Devitrification of natural glass, Geol. Soc. Am. Buit., 72, p. 1493-1520. NNA.900215.0056.

Mazer, J. J., 1987, Kinelics of glass dissolution as a function of tcmperature. glass composition, and solution $\mathrm{pHs}$, Unpub, Ph.D. dissertation, Northwestern University, 179 p. NNA.900216.0062.

McCarthy, G. J., Schcetz, B. E., Komarneni, S., Smith, D. K., and While, W. B., 1980, Hydrothermal stability of simulated radioactive waste glass. in. Solid State Chemistry: 1 Contemporary Onerview. Holt, S. L. Milstein. J. B., and Robbins, M., eds., The Amcrican Chemical Society Advances in Chemistry Series 186, p. 349-398. NNA.900315.0297.

MeGrail, B. P., 3988. Modeling the dissolution behavior of defense waste glass in a salt repository environment, Mat, Res. Soc. Symp. Proc., 112, p. 595-606. NNA.900206.0096. 
McGrail, B. P., Kumar, A., and Day, D. E, Sodiem diffusion in the and leaching of simulated nuclear waste glass, J. Amer. Cer. Soc., 67, p. 463-467. NNA.900312.0164.

McKenzie, W. F.. Wolery, T. J., Delany, J. M., Silva, R. J., Jackson, K. J., Bourcicr, W. L., Emerson, D. O. 1986, Geochemical Modeling (EQ3/6) Plan, Office of Clvilian Radioactive Waste Management P-ogram, Lawrence Livermore National Laboratory, UCID-20864, 75 p. NNt.881209.0024.

McVay, G. L, and Buckwalter, C. Q., 1983, Efiect of iron on waste-glass leaching, J. Am. Cer. Soc., 66 (3). p. 170-184. NNA.900306.0097.

Melnyk, T. W., Walton, F. B., and Johnson, L. H., 1984, High-level waste glass ficld burial tesl: Leaching and migration of fission products, Nuct. Chem. Waste Management, 5, p. 49-62. NNA. 900306.0097 .

Melson. W. G., 1973, Basaltic glasses Irom the Deep Sea Drilling Projecl. Chemical characterislics, compositions of alteration products, and fission tract "ages", Trans. Am. Cieophys. Union, 54, p. 1011-1014. NNA.900306.0099.

Melson, W. G., and Thompson, G., 1973, Glassy abyssal basalts, Allantic scafloor ncar St Pauls's Rocks: petrography and composition of secondary clay minerals. Geol. Soc. Am. Bull., 84, p. 703716. NNA.900306.0100.

Melson, W. G., Byerly, G. R., Nelen, J. A., O'Heam, T., Wright, T. L.. and Vallier. T., 1977. A catalog of the major element chemistry of abyssal volcanic glasses, Smithsonian Contrib. Earth Sci., 19, p. 31-60. NNA.900312.0165.

Mendel, J. E., 1982, The measuremem of leach rates: A review, Nucl. Chem. Waste Managemeni.3, p. 117-123. NNA.900312.0166.

Michels, J. W., Tsong. 1. S. T., and Nelson, C. M., 1983a, Obsidian daling and East African archacology. Science, 219 . p. 361-366. NNA.900312.0168.

Michcls, J. W., Tsong, I. S. T., and Smith, G. A., 1983b, Experimentally derived hydration rates in obsidian dating, Archaeometry, 25, p. 107-117. NNA.900312.0167.

Moore, J. G., 1966, Rate of palagonitization of submarine basalt adjacent to llawdii, U. S. Gcol. Survcy Prof. Paper 550-D, p. D163-D171. NNA.900312.0169.

Moore, J. G., Forni, D. J." and Clague, D. A., 1985, Dasalts from the 1877 submarine eruption of Mauna Lod, Hawaii: New data an the variation of palagonization rate with temparalure, $U_{n} S$. Geol. Survey Bull. 1663, 11 p. NNA.900315.0298.

Morgenstein, M., ar, Piley, T. J., 1975, Hydration-rind dating of basaltic glass: A new method for archeological chronologies, Asian Perspectives, 17, p. 145-159. NNA.900315.0299.

Morgenstein, M., and Rosendahl, P., 1976, Basattic glass hydration dating in Hawaiian archacology, in. Advances in Obsidian Glass Studies, Taylor, R. E., ed., Noyes Press, Park Ridge. NJ. p. 141-164. NNA.900405.0459.

Moriga, $Y$. and Nogami, M., 1980, Hydration of silicale glass in stcam atmospherc. J. Non-Cryst. Solids. 38/39, p. 667-672. NNA.900306.0101. 
Mott, M. J., and Holland, H. D., 1978, Chemical exchange during hydrothermal alteration of basalt by scawatir - I. Experimental results for major and minor components of seawater, Geachim. Cosmochim. Acra. 42, p. 1103-1115. NNA.900306.0102.

Mouchc, E., and Vernaz, E., 1988, Aqueous corrosion of the French LWR solution reference glass: Firsl generation model. Mat. Res. Soc. Symp. Proc., 112. p. 703-712. NNA.900306.0103.

Muchlenbachs, K. and Clayton, R. N., 1972, Oxygen isotope studics of fresh and weathered submarine basalts, Can. J. Earth Sei., 9. p. 172-184, NNA.900306.0104.

Murfer, L. J. P., Short, I. M., Keith, T. E. C., and Smith, V. C., 1969, Chemistry of fresh and altered basaltic glass from the Upper Triassic Hound Island voleanics, southeastern Alaska. Am. J. Sci., 267, p. 196-209. NNA.900306.0105.

Murakami, T. and Banba, T., 1984, The leaching behavior of a glass wastc form-Part 1: The characteristics of surface layers, Nuci. Technol., 67, p. 419-428. NNA.900312.0170.

Murakami, T., Ewing, R. C., and Bunker, B. C.. 1988, Analytical clectron microscopy of leached layers on synthetic basalt slass, Mat. Res. Soc. Symp. Proc., 112, p. 737-750. NNA.900306.0106.

Natland, J. H., and Melson, W. G., 1980, Composition of basaltic glasses from the East Pacifie Rise and Siquciros fracture zone, near $9^{\circ} \mathrm{N}$, in, Initial Report of the Deep Sea Drilling Project 54, Rosendahl B. R. et al., eds., U. S. Government Printing Ofrice, Washington, D. C., p. 705-723. NNA. 900315.0300 .

Nayudu, Y. R., 1964. Palagonilc tuffs (haloclastites) and the products of post-cruplive processes. Bull. Volc., 27, p. 391-410. NNA.900306.0107.

Newton. R. G., and Paul. A., 1980, A new approach to predicting the durability of glasses. Glass. Tech., 21, p. 301. NNA.900215.0063.

Nogues, 3. L., Vernat, E. Y., and Jacquet-Francillon. N., 1985, Nuclear glass corrosion mechanisms applicd to the French LWR reference glass, Mat. Res. Soc, Symp. Proc., 44, p. 89-98. NNA.900212.0057.

Nogucs, J. L., Vcrnaz, E. Y., Jacquet-Fiancillon, N., and Pasquini, S.. 1985, Alterability of the Fresch LWR solution reference glass in repository conditions. Mat. Res. Sac. Symp. Proc. 44, p. 195-204. NNA.901215.0058.

O'Keefe. J. A., Barkall, A., Glass, B. P., and Alterescu, S., 1988, Nuclear Waste under glass, further Jiscussion, EOS Trans. AGU, 70, p. 860. NNA.900215.0059.

Ougouag, A. M., and Machicls, A. J., 1985, E[rects of tadiation-induced stress on the chemical durability of nuclcar wastc glass, Mas. Res. Soc. Symp. Proc., 44, p, 609-616. NNA.900215.0060.

Palmer, H. C., Tazaki, K., Fyle, W. S., and Zhou, Z., 1988, Precambrian glass, Geology. 16, p. 221224. NNA.900215.0061.

Parkhurst, D. L., Thorstenson, D. C., and Plummer, L. N., 1980, PHREEQE- A compuser program for geochemicol calculations, Watcr-resources Investigations 80-96, U. S. Gcolugical Survey. Reston, VA, 210 P. HQS.8M0517.2817.

Paul, A.. 1977, Chemical durability of glasscs: A thermodynamic approach. J. Maseriats Science, 12. p. 2246-2268. HQS.880517.2522. 
Paul, A., 1982, Chemisiry of Glosses, Chapman and Hall, 293 p. NNA.900216.0063.

Paul, A., and Zeman, M, S., 1978, The relative infuence of A1203 and Fe2O3 on the chemical durability of silicate glasses at different pH valucs, $J$. Materials Science, 13, p. 1499-1502. NNA.900306.0108.

Pcacock, M. A., 1926. The volcano-glacial Palagorite Formation of Iccland, Geol. Mag., 63, p. 385399. NNA.900312.0173.

Peacock, M. A., and Fuller, R. E., 1928, Chorophacite, sideromelanc, and palagonite from the Columbir River Plateau, Am. Min., 13, p. 260-282. NNA.900312.0172.

Pederson, L. R. Baer, D. R., MeVay, G. L., and Engelhard, M. H., 1986. Reaction of soda lime glass in isotopically labelled water, Jour. Non-Cryst. Solids, 86, p. 369-380. NNA.9010306.0109.

Pederson, L. R. and McVay, G. L., 1983, Infuence of gamma irradiation on Ieaching of simulated nuelear waste glass: Temperatuse and dose rate dependence in deacrated waler, J. Am. Ceram. Soc., 66. p. 863-867. NNA.900306.0110.

Pederson, L. R. and McVay, G. L., 1984, Efrect of gamma radiolysis on waste glass leaching on brines, in, Advances in Ceramics 8, Wicks, G. G. and Ross, W. A., cds., The American Ceramic Socicly, Culumbus, OH, p. 49-56. NNA.900315.0301.

Pescatore, C., and Machiels, A. J,, 1983, Mechartistic approach to modelling of nuclear waste form leaching, in, Advances in Ceramics 8, Nuclear Waste Management. Wicks, G. G, and Ross. W. A. eds., Amer. Cer. Soc., Columbus, OH, p. 509-518. NNA.900215.0062.

Petit, J. C.. Langevin, Y., Lameille, J. M., and Dran, J. C., 1982, On the leaching behaviur of a simple borosilicate glass in a confined environment, Mas. Res. Soc. Symp. Proc., 11. p. 203-210. NNA.900306.0111.

Pjetursson, H., 1900, The glacial palagonite formation of lceland, Scoltish Geog. Mag., 16, p. 265293. NNA.900312.0174.

Plodinec, M. J., Jaltzen, C. M., and Wicks, G. G., 1984a, Thermodynamic approach to prediction of the stability of proposed radwaste glasses, 2 nd Int. Symp. Ceramics in Nuclear Waste Management, Wicks, G. G., and Ross, W., eds., American Ceramic Society, p. 493-495. NNA.900215.0064.

Plodince, M. J., Jantzen, C. M.. and Wicks, G. G., 1984b, Stability of radinaclive wastc glasses asscssed from hydration thermodynamics, Mal. Res. Soc. Symp. Proc., 26, p. 755-762. NNA.900215.0065.

PNL, 1984, Final report of the defense high level waste teaching mechanisms program. PNL-5157. Pacific Northwest Laboratory. August, 1984. HQS.8B0517.2498.

Pritchard, R. G., Cann, J. R., and Wood, D. A., 1978. Low temperature alteration of hasslis, Leg 49. in, Cann, J. R. et al., eds., Initial Reports of the Deep Sea Drilling Project, 49, U. S. Government Printing Orfice. Washington, D. C., p. 709.714. NNA.900315.0302.

Rana, M, A., and Douglar, R. W., 1961a, The reaction between glass and walcr, Part 1. Experimental methods and obscrvations, Phys. Chem. Giasses, 2, p. 179.195. NNA.900312.0175. 
Rana, M. A., and Dougles, R. W., 1961b, The reaction beteen glass and water. Part 2. Discussion of the results, Phys. Chem. Glasses, 2, p. 196-205. NNA.900312.0176.

Richet, P., and Boltinga, Y. 1986, Thermochemical properties of silicate glasses and liquids: A review. Reviews of Geophysics, 24, p. 1-25. NNA.900215.0066.

Rimstidt, J. D. and Barnes, H. L., 1980, The kinetics of silica-water reactions, Geochim. Cosmochim. Ac1a. 44. p. 1683-1699. HQS.880517.2528.

Robinson, P. T., Melson, W. G., O'Hearn, T., and Schmincke, H. -U, 1983, Volcanic glass compositions of the Troodos ophiolite, Cyprus, Geology, 11, p. 400-404. NNA.900306.0113.

Rutley, F., 1886, Notes on alteration induced by heal in ccriain vitreous rocks, Royal Soc. London Proc., 40, p. 1071-1089. NNA.900315.0303.

Sales, B. C., Whitc, C. W., Begun, G. M., and Boatner, L. A., 1984, Surface layer formation on corroded nuclear waste glasses, J. Non-Cryst. Solids, 67. p. 245-264. NNA.900306.0112.

Savage, D., Robbins, J. E., and Merriman, R. J., 1985. Hydrothermal crystallization of radiaactive waste storage glass, Min. Mag.. 49. p. 195-201. NNA.900312.0178.

Scarfc, C. M. and Smith, D. G. W., 1977, Secondary minercis in some basaltic mincrats from DSDP Leg 37, Con. J. Earth Sci., 14, p. 903-910. NNA.900312.0179.

Schedr, B. E., Frebom, W. P., Smith, D. K.. Anderson, C., Zolensky. M., and While, W. B., 1985. The role of boron in monitoring the leaching of borosilicate glass waste forms, Mas. Res. Soc. Symp. Proc., 44, p. 129-134. NNA.900215.0068.

Scheidegger, K, F., and Stakes. D. S., 1979, X-ruy diffraction and chemical study of secondary miserals from Deep Sca Drilling Project Leg 51, Holes 417A and 41,D, in, Init. Rep. DSDP 51, 52. 53. Donnclly, J. ct al., cds., p. 1253-1263. NNA.900430.0051.

Schindicr, P. W., Furst, B., Dick, R., and Wolf, P. U., 1976, Ligand papcries of surface silanol groups, I. Surface complex formation with $\mathrm{Fe}^{3+}, \mathrm{Cu}^{2+}, \mathrm{Cd}^{2+}, \mathrm{Pb}^{2+}, J$. Colloid and Inierface Science. 55. p. 469.475, NNA,900306.0114.

Schmincke, H. -U., 1983. Ash laycrs, hyaloclastites, and alteration of basaltic glass, Leg 65, in, Initial Reports of the Deep Sea Drilling Project 65, Lewis, B. T. R., et al., eds., U. S. Govenmen! Printing Orficc. Washington, D. C., p. 477-483. NNA.900315.0304.

Schmincke. H. -U., and Pritchard, G., 1981, Carboniferous volcanic glass from submarine hyaluclaslite, Lahn-Dill area, Germany, Nalurwissenschaften, 67, p. 615. NNA.900312.01B1.

Schminckc, H. -U., Robinson. P. T., Ohrmacht, W., and Flowcr, M. F. J., 1978. Basalic hyaloclastitcs from Holc 396B, DSDP Leg 46, in. Inirial Reports of the Deep Sea Drilling Project 46. Dmitricv, L. et al., eds., U. S, Government Printing Office, Washinglon, D. C., p. 341-355. NNA.900315.0305.

Scholrc, H., 198R. Glass-water inleractions, J. Non-cryst. soluds, 102, p. 1-10. NNA.900215,0067.

Scholzc, H., Concadi, R., Engelke, H., and Roggendorl, H.. 1982. Detcrmination of the corrosion mecianism of high-lcuel waste containing glass, in, Scientlfic Basis for Nuclear Waste Management V, Lulze, W., ed., North Holland, New York. p. 173-180. NNA.900306.0115. 
Schramke, J. A., Simonson, S. A., and Coles, D. G., $1985 .{ }^{237} \mathrm{~Np}$ and ${ }^{239} \mathrm{Pu}$ solution bchavior during hydrothermal testing of simulated nuclear watc glass with basalt and steel. Mat. Res. Soc. Symp. Proc. 44, p. 343-350. NNA.900306.0116.

Seyfried, W. E., and Bischoff, J. L., 1979, Low-temperature basatt atteration by scawater: An experimental study at $70^{\circ} \mathrm{C}$ and $150^{\circ} \mathrm{C}$. Geochim. Cosmochim. icta. 43, p. 1937-1947. NNA.900306.0117.

Shade, J. W., Pederson, L. R., and McVay, G. L., 1983, Waste glass-metal inlcractions in brines, in, Advances in Ceramics 8, Nuelear Waste Management, Wicks, G. G., and Ross, W. A., cds., The American Ceramic Saciety. Columbus. Ohio, p. 358-367. NNA.900320.0152.

Singer, A., 1974, Mineralogy of palagonitic material from the Golan Heights, Israel, Clays Clay Min. 22. p. 231-240. NNA.900306.0118.

Smets, B. M. J., and Lommen. T. P. A., 1982. The leaching of sodium aluminosilicate glasses studied by secondary ion mass spectrometry, Phys. Chem. Glosses, 23, p. 83-87. NNA.900215.0069.

Smets, B. M. J., Tholen, M. G. W., and Lommen, T. P. A., 1984, The elfects of divalent cations on the Icaching kinetics of glass, $J$. Non-Cryst. Solids, 65, p. 319-332. NNA.900215.01070.

Smetc. B. M. J., and Tholen. M. G. W.. 1985. The pH dependence of the aqueous corrosion of glass, Phys. Chem. Glasses, 26, p. 60.63. NNA.900215.0071.

Stakes, D. S., and O'Neil, J. R., 1982, Mineralogy and stable isotope geochemistry of hydrothermalify altered oceanic rocks, Earlh Planet. Sci. Lett., 57, p. 285-304. NNA.900306.0.119.

Staudigcl, H., and Hart, S. R., 1983, Alteration of basaltic glass: Mechanisms and significance for the oceanic crust-seawater budget, Geochim. Cosmochim Acta, 47, p. 337-350. NNA.900215.0072.

Stokes, K. R., 1971, Further investigations into the nature of the materials chlorophacite and palagonile, Min. Mag.38, p. 205-214, NNA.900312.0183.

Store, J. A., 1981, An overview of factors affecting the leachability of nuclear waste forms, Nucl. Chem. Waste Management, 2, p. 113-118. NNA.900306.0120.

Strdehat, D. M., 1984, Erfect of How rate on the lcaching of nuclear waste glass, in, Advances in Ceramics 8. Wicks, G. G. and Ross . W. A., eds., The American Ceramic Socicty. Columbus, OH. p. 12-18. NNA.900320.0146.

Strachan, D. M., Krupka, K. M., and Grambow, B., 1984. Solubility interpretations of leach tests on nuclear waste glass. Nuclear and Chemical Waste Management, 5. p. 87-99. HQS.880517.2547.

Sturchio, N. C., and Scilz, M. C., 1985. Bchavior of nuelear waste elements during hyourotiermal alteration of glassy shyolite in an active geothermal system: Yeiiowstone National Park. Wyoming, Mat. Res. Soc.Symp. Proc., 44, p. 557-564. NNA.900215.0073.

Sullivan, T. M., and Machicls. A. 1., 1984, Modeling chemical interactions in the hydrated layers of nuclear waste glasses. Mar. Res. Soc. Symp. Proc.. 26, p. 597-604. NNA.901215.0074.

Thomas, D., 1987. A zecchemical model of the Kilaued East Rift Zone, U. S. Geal. Surv. Pror. Pap. 1350, p. 1507-1525. NNA.900215.0075. 
Tomasson, J.. and Kristmannsdothir, H., 1972. High temperature alteration mincrals and thermal brines Reykjancs, Iccland, Contrib. Mineral. Petrol, 36, p. 123-134. NNA.900306.0121.

Tsong. I. S. T., Smith, G. A., Michels, J. W., Wintenberg, A. L., Miller, P. D., and Moak, C. D., 1981, Dating obsidian artifacts by depth-profiling of artificially hydrated surface layers, $J$. Nucl. Instrum. Mesh., 191. p. 403-407. NNA.900312.0184.

Tsukamoto, M., Bjomer, 1., Christensen, H., Hermansson, H. -P, and Werme, L., 1988, Leaching of Am-241 from a radioactive waste glass corroded in the presence of staninless stecl corrosion products and/or bentonite, Mat. Res. Soc. Symp. Proc., 112, p. 565-574, NNA.900306.0122.

Tucholkc, B. E. et al., 1979, Initial Reports of the Deep Sea Drilling Project, 43, U. S. Government Printing OfJice, Washinglon, D. C., p. xxiii-xxv. NNA.900320.0147.

Uhlmann, D. R., 1972, A kinetic Irealment of glass formation, J. Noncrysdalline Solids, 7, p. 337348. NNA.900306.0123.

Van Jseghem, P., and Grambow, B., 1988. The long-term corrosion and modelling of two simulated BeIgian reference high-level waste glasscs, Mat. Res. Soc. Symp. Proc.. 112. p. 631-640. NNA.900306.0124.

Van Iseghem, P. Ph., Timmermans, and De Batist, R., 1985, Parametric sludy of the corrosion behaviour in static distilled water of simulated European reference high level waste glasses, Mat. Res. Soc. Symp. Proc., 44, p. 55-62. NNA.900215.0076.

Veldc, B., 1985. Clay Minerals: A Physico-Chemica! Explanation of their Occurrence, Elscvier, Amsicrdam, p. 1-6. NNA.900320.0148.

Vernaz, E. Y., Dussossoy, J. L., and Fillel, :988, Ternperature dependence of R7T7 nuclear wate glass, Mar. Res. Soc. Symp. Proc., 112. p. 555-564. NNA.900306.0125.

Walker, D. D., Wilcy. J. R., Dukes, M. D., and LeRoy, J. H., 1982, Leach rale studics on glass containing actual radioactive waste. Nucl. Chem. Waste Management, 3, p. 91-94. NNA.901312.0185.

Wallace, R. M. and Wicks. G. G., 1983. Leaching chemistry of defense borosilicate glass, Mat. Ree. Soc. Symp. Proc, 15, p. 23-28, NNA.900306.0126.

Wallers, H, V., and Adams, P. B., 1975, Erfects of humidity on weathering of glass, $J$. Non-Cryst. Solids. 19. p. 143-199. NNA.900312.0186.

Wermc. L. O., and Grambow, B., 1987, Development, application and validation of mode's for waste package long-term performance: current trends, Mat. Res. Sof. Symp. Proc., 84, p. 29-43. NNA.900215.0077.

Wermi, L. O., Hench, L. L., and Lodding, A, 1985, Nuclear wasle glass interfaces after 1 year burial in Stripa, Mat. Res. Soc. Symp. Proc.. 44, p. 37-44. NNA.900215.0078.

While, A, F., 1983. Surface chemistry and dissolulion kinetics of glassy rocks at $25^{\circ} \mathrm{C}, \boldsymbol{G e o c h i m}$. Cosmochim. Acta, 47, p. 805-815. NNA.900312.0188.

Whitc, A. F., and Claasen, N. C., 2980. Kinctic ntodel for the short-lerm dissolution of a rhyolytic glass, Chemical Ceology, 2A, p. 91-109. NNA.9003016.0127. 
White. W. B., 1986, Dissolution mechanisms of nuclear waste glasses: Critical review, Advances in Ceramics 20, p. 431-442. NNA.900215.0079.

Wicks, G. O., 1986, Nuclear waste vitrification - The geology connection, J. Non-Cyrst. Solids, 84 , p. 241-250. NNA.900215.0080.

Wicks, G. G., Rankin, W, D., and Gore, S. L., 1985, International waste glass study - composition and leackability correlations, Hat. Res. Soc. Symp. Proc, 44, p. 171-177. NNA.900215.0081.

Wicks, O. G., Robnet, B. M., and Rankin, W. E., 1982, Setentific Basis for Nuclear Waste Mangement, 5. Lulze, W., ed., Elsevier, New York, p. 15. NNA.900306.0128.

Wolery. T. J., 1979. Calculation of chemical equllibrium between aqueous solutions and minerals: The EQ3/6 sofiware package, Lawrence Livcrmore National Laboratory Repurt UCRL-52658. Livcrmore, CA, 41 p. HQS.880517.2586.

Wood, B. J., and Walther, J. V., 1983, Rates of hydrothermal rcactions, Science, 222. p. 413-415. NNA.900312.0189.

Yokoyam, H., Hermansson, H-P, Christensen, H., Bjorner, I-K, and Werme, L., Corrosion of simulated nuclear waste glass in a gamma radiation ficld, Mat. Res. Soc. Symp. Proc., 44, p. 601-607. NNA.900215.0082.

Zellmer, L. A., and White, W. B., 1985, Characterization of hydrated surface layers on nuclcar waste glasses by infrared reflectance spectroscopy. Mat. Res. Soc. Symp. Proc., 44, p. 73-80. NNA.900215.0083.

Zhu, Bing-Fu, Clark, D. E., Hench, L. L., Wicks, G. G., and Werme, L., 1985, One-year lcaching of three SRL glasses in granite, Mat. Res. Soc. Symp. Proc., 44, p. 187-194. NNA.901215.0084.

Zhou, Z., and Fyfe, W. S., 1988, A comparative experimental study of glass stability in scawater and distilled water, Mat. Res. Soc. Symp. Proc., 112, p. 725-736. NNA.900306.0129.

Ziclinski, R. A. 1980. Stability of glass in the geologic environment: Some evidence fron. studies of natusal silicate giasses, Nuclear Technology, 51, p. 197-200. NNA.900215.0085. 